


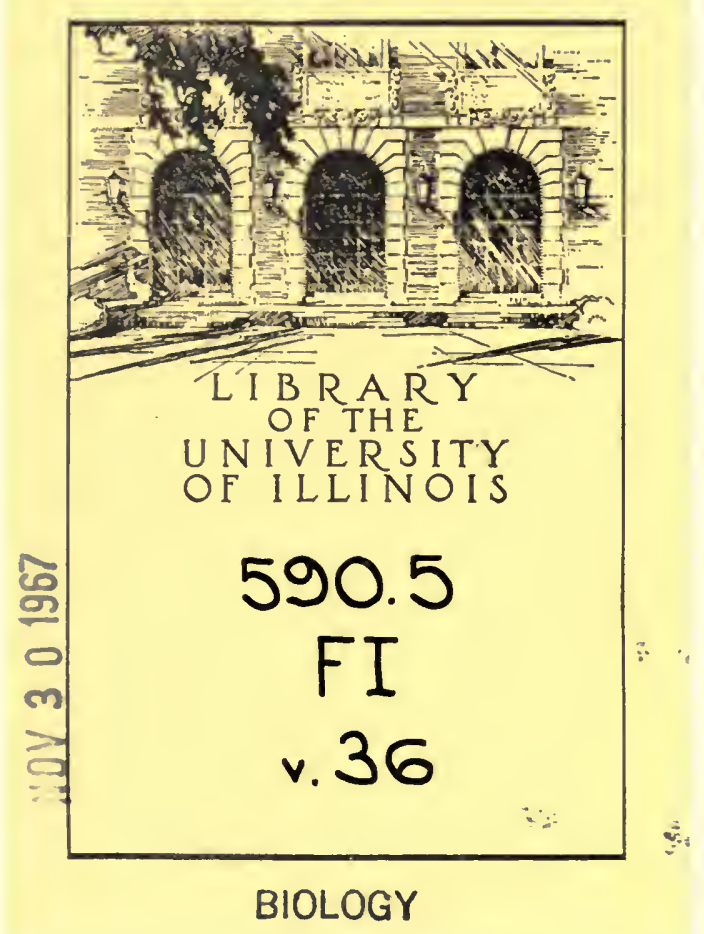


The person charging this material is responsible for its return on or before the Latest Date stamped below.

Theft, mutilation, and underlining of books

are reasons for disciplinary action and may

result in dismissal from the University.

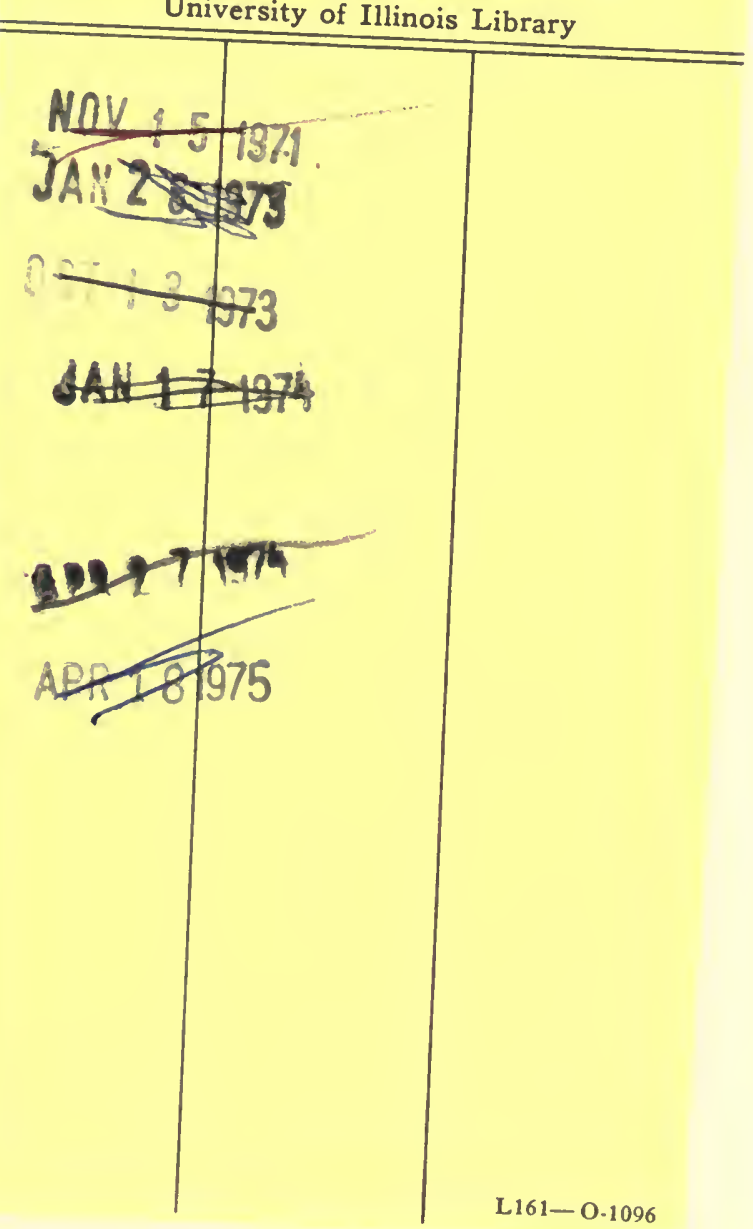





REPORT ON A COLLECTION OF MARINE FISHES FROM NORTH BORNEO

ROBERT F. INGER

FIELDIANA: ZOOLOGY

VOLUME 36 , NUMBER 3

Published by

CHICAGO NATURAL HISTORY MUSEUM

MAY 29, 1957

THE LIBRAFY OF THE

JUN 101957 


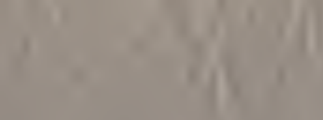

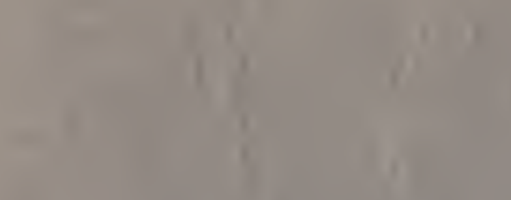

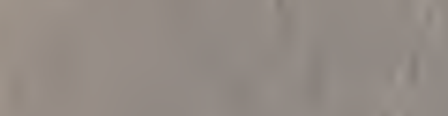

$$
\begin{aligned}
& \text { in, } \\
& \text { and }=3,1
\end{aligned}
$$

(1)

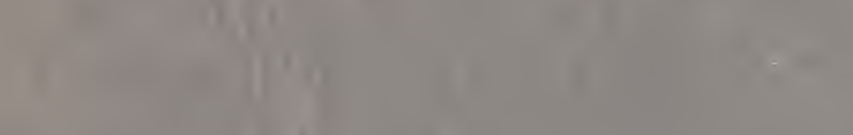

I

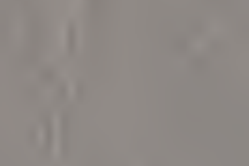

Whin $^{\prime}$

I i i

(1) 


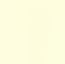





\title{
REPORT ON A COLLECTION OF
}

\section{MARINE FISHES FROM NORTH BORNEO}

\author{
ROBERT F. INGER
}

Curator, Division of Amphibians and Reptiles

FIELDIANA: ZOOLOGY VOLUME 36 , NUMBER 3

Published by CHICAGO NATURAL HISTORY MUSEUM MAY 29, 1957

IHE LIBRARY OF THE JUN 101957 
PRINTED IN THE UNITED STATES OF AMERICA BY CHICAGO NATURAL HISTORY MUSEUM PRESS 


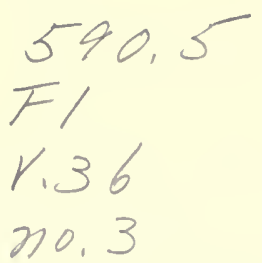

INTRODUCTION

PAGE

Annotated List of Species

Dussumieridae

Clupeidae

Engraulidae

Ophichthyidae

Muraenidae

Plotosidae

Synodontidae

Hemiramphidae

Bothidae 355

Soleidae 355

Holocentridae 355

Syngnathidae 357

Fistulariidae 357

Carangidae 357

Apogonidae 358

Sillaginidae 362

Leiognathidae 362

Gerridae 363

Ambassidae 363

Serranidae 363

Centropomidae 366

Pseudochromidae 366

Theraponidae 367

Lutianidae 368

Mullidae 370

Zanclidae 371

Chaetodontidae 371

Acanthuridae

Siganidae 373

Atherinidae 374

Sphyraenidae 374

Scorpaenidae 375 
Pomacentridae .................... 376

Labridae . . . . . . . . . . . . . . . . 385

Scaridae . . . . . . . . . . . . . 391

Gobiidae . . . . . . . . . . . . . . . . . . . . 392

Eleotridae . . . . . . . . . . . . . . 397

Opisthognathidae . . . . . . . . . . . . . . . . . . 398

Callionymidae . . . . . . . . . . . . . . . . . . . . 399

Blenniidae . . . . . . . . . . . . . . . . 399

Congrogadidae ................... . . 400

Brotulidae . . . . . . . . . . . . . . . . . . . 401

Pholidichthyidae . . . . . . . . . . . . . . . . . . 401

Triacanthidae . . . . . . . . . . . . . . . . . 401

Monacanthidae . . . . . . . . . . . . . . . . 402

Balistidae . . . . . . . . . . . . . . . . 402

Tetraodontidae . . . . . . . . . . . . . 403

Ostraciidae . . . . . . . . . . . . . . 404

Diodontidae . . . . . . . . . . . . . . . 404

REFERENCES .. . . . . . . . . . . . . . . . 404 


\section{Marine Fishes From North Borneo}

\section{N T R O D U C T I O N}

Of the many Bornean collections of fishes reported on by Bleeker (1851-60, various journals), none came from coral reefs. Indeed, only one collection of fishes from a Bornean coral reef has been noted in the literature. In September, 1909, the United States Bureau of Fisheries steamer Albatross collected fishes from a coral reef on Danawan Island in Darvel Bay, North Borneo. The report on the Albatross material, begun by Fowler and Bean (1928), has not been published in full.

The bulk of the marine fishes collected by the Borneo Zoological Expedition, 1950, of Chicago Natural History Museum, came from a shallow coral reef. Almost half of the species have not previously been recorded from Borneo or its offshore islands. The specimens are from four localities (fig. 5), the largest number from Pulo Bakkungaan Kechil, a small island 14 kilometers off the mouth of Labuk Bay. Fishes were collected at two stations on this island on August 24 and 25, 1950.

A shallow, sandy shelf, varying from 20 to 150 meters in width, surrounds Bakkungaan Kechil. Coral reefs are present on this shelf on the north and west. A part of the western reef, a triangle roughly 40 by 60 by 70 meters, was poisoned with cubé root ( 5 per cent rotenone). The poison was broadcast at 3:30 P.M., approximately one hour before low tide, at which time the maximum depth of the station was 1.5 meters. The water was clear. The coral occupied about 80 per cent of the bottom. The maximum size of the coral lumps was 3 meters in diameter and $60 \mathrm{~cm}$. in depth. Exposed channels of sand did not exceed a width of $60 \mathrm{~cm}$. At 5:30 P.M. healthy fishes of the species (various pomacentrids) first affected by the rotenone were swimming normally through the station; 127 species were obtained during this two-hour interval.

The second station was established along the sandy beach among shallow tide pools south of the western reef. There was 
no living coral, but dead fragments up to $15 \mathrm{~cm}$. in diameter were strewn through the area. Several coconut palm logs were lying in the water. Schools of Sardinella leiogaster swam through the

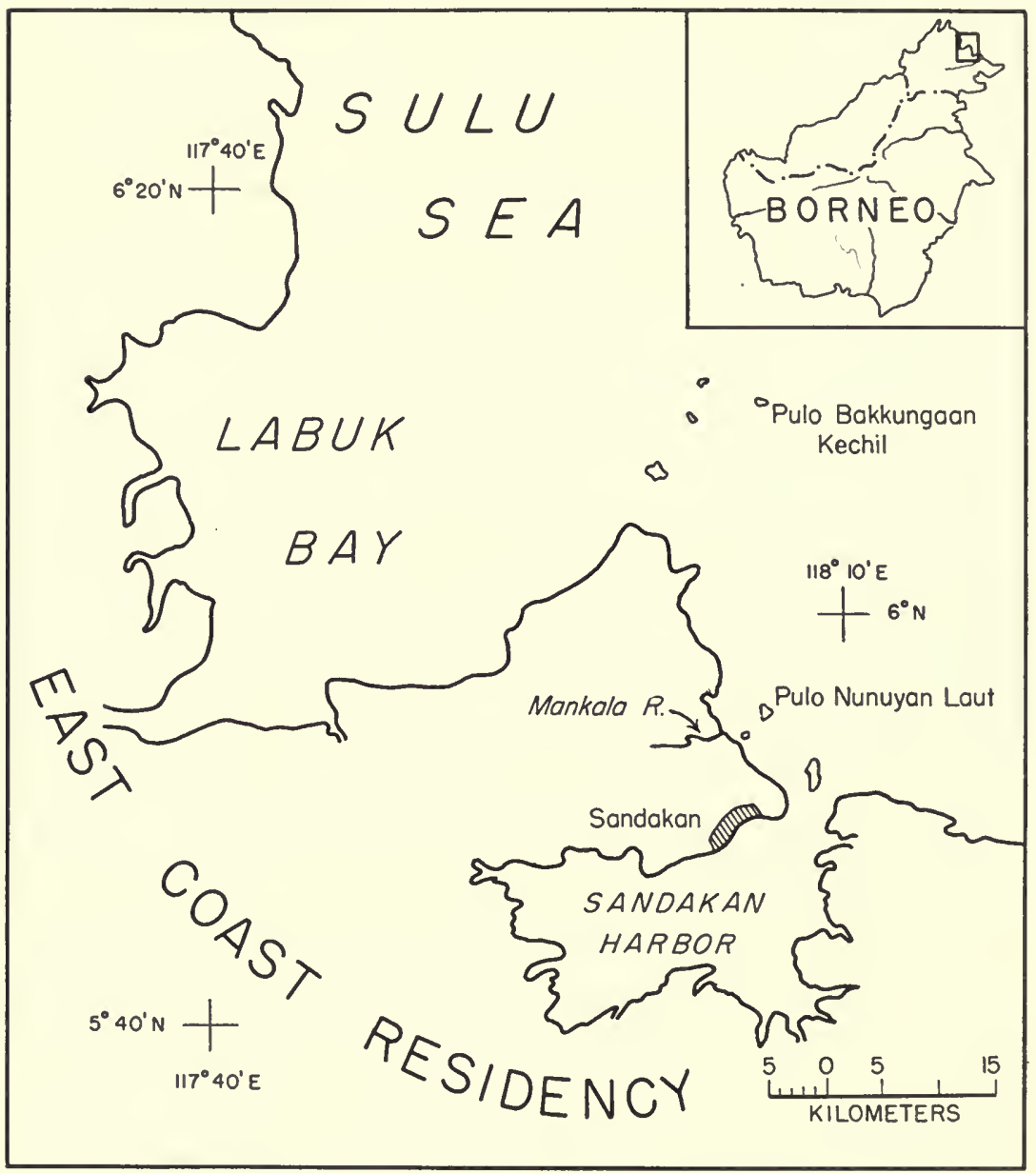

FIG. 5. Map of the northeastern coast of North Borneo showing collecting localities.

open water, but most of the other species collected remained at the edges or under the coral fragments and palm logs. Cube root was broadcast at 2:30 P.M. Collecting, continued until low tide two hours later, yielded 44 species, of which 19 were not obtained on the reef. 
A third collection was made on April 28, 1950, off Pulo Nunuyan Laut, a small island 3 kilometers offshore and 9 kilometers north of the entrance of Sandakan Harbor (fig. 5). Coral is abundant in the shallow water between Nunuyan Laut and Borneo, but it does not develop into reefs. The water carries sediment out of Sandakan Harbor and so it is not as clear as at Bakkungaan Kechil. The collecting site was one kilometer southwest of Nunuyan Laut, in water less than 1.5 meters deep. Cubé root was spread at 2:00 P.M. and specimens were collected for one and one-half hours. Only 38 species were obtained.

Directly opposite Nunuyan Laut, a fourth station was established inshore just south of the mouth of the Mankala River. The bottom consisted of mud and sand adjacent to the river mouth, and sand and coral farther south. Ten species were collected by means of cast nets and a beach seine.

Marine fishes were also obtained at the Sandakan Fish Market. Although exact localities for these specimens are unknown, they presumably were caught within 50 kilometers of Sandakan.

Of the 83 species recorded from Borneo and its offshore islands for the first time, the majority are widely distributed (i.e., from the western portion of the Indian Ocean to beyond the East Indies, or from the East Indies to Polynesia) as may be seen in the following tabulation of their ranges:

Circumtropical. ................................. 1

Western border ${ }^{1}$ of Indian Ocean to Polynesia . . . . . . . . . . . . . . . . 29

Western border of Indian Ocean to Micronesia . . . . . . . . . . . . . . 4

Western border of Indian Ocean to Melanesia . . . . . . . . . . . . . 5

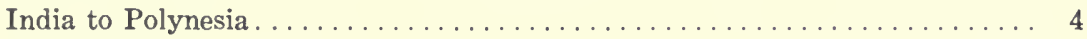

East Indies to Polynesia . . . . . . . . . . . . . . . . . . . . . . 14

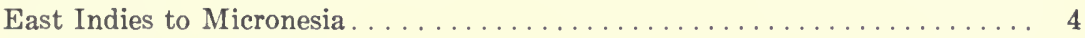

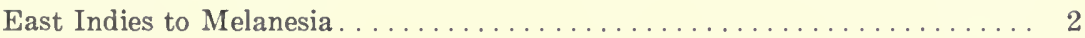

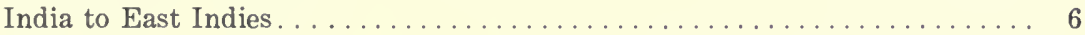

East Indies to Australia . . . . . . . . . . . . . . . . . . . . . . 3

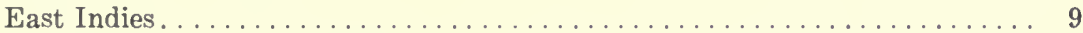

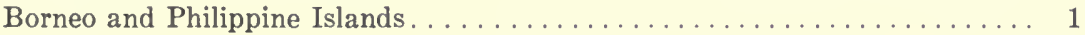

Borneo......................................... 1

Of the species endemic to the East Indies, six (Ichthyocampus kampeni, Holocentrus cornutus, Nematachromis annae, Diproctacanthus xanthurus, Halichoeres amboinensis, and Gunellichthys

1 The "western border" of the Indian Ocean is here considered to be the area including the Red Sea, the coast of East Africa, and the islands off the coast of East Africa. 
pleurotaenia) are known only from the area east of the Sunda Shelf, that is, east of a line connecting the Bali Strait with the southeastern tip of Borneo. The remaining three (Holocentrus lacteoguttatum, Abudefduf oxyodon, and Pseudogobius javanicus) are recorded from both eastern and western parts of the archipelago.

No part of this collection could have been obtained without the aid of the Fisheries Department, Colony of North Borneo. To Messrs. J. A. Tubb and A. M. Anderson, formerly Director and Assistant Director of Fisheries, respectively, and to their entire staff I am indebted for assistance and co-operation in the field and in the Fisheries Department laboratory.

Methods.-Except where specifically stated otherwise, the following definitions apply throughout. Total length was taken as the overall length, standard length was measured from the tip of the head to the caudal flexure, head length from the tip of the head to the end of the opercular flap, and body depth at the maximum depth. Measurements below $120 \mathrm{~mm}$. were made with vernier calipers graduated to $0.1 \mathrm{~mm}$.; above $120 \mathrm{~mm}$. a steel rule graduated to $0.5 \mathrm{~mm}$. was used.

The ratios of standard length to head length and body depth are noted as "head" and "depth," the ratio of head length to eye diameter as "eye."

Only those fin rays having separate bases were counted. Lateral line scale counts do not include scales beyond the caudal flexure. Where more than five observations were available, the means and their standard error are given in parentheses after the character, and the number of observations indicated by "N." The number of specimens from each locality is given in parentheses.

Species not previously reported from Borneo are indicated by an asterisk.

\section{ANNOTATED LIST OF SPECIES}

\section{ISOSPONDYLI}

\section{DUSSUMIERIDAE}

\section{Spratelloides delicatulus Bennett}

Clupea delicatula Bennett, 1831, Proc. Zool. Soc. London, 1831-31: 168Mauritius.

Spratelloides delicatulus Günther, 1868, Cat. Fishes Brit. Mus., 7: 464; Weber and de Beaufort, 1913, Fishes Indo-Austr. Arch., 2: 20. 
Dorsal 10-11; pectoral i,11; ventral i,7; anal 9-10; mid-lateral scales 37 ; total length $50.5-58 \mathrm{~mm}$.; standard length $42.3-51 \mathrm{~mm}$.; head 3.71-3.86; depth 5.64-5.80.

Pulo Bakkungaan Kechil. Reef (2).

\section{CLUPEIDAE}

\section{*Sardinella leiogaster Valenciennes}

Sardinella leiogaster Valenciennes in Cuvier and Valenciennes, 1847, Hist. Nat. Poissons, 20: 270 -East Indies.

Clupea (Amblygaster) leiogaster Weber and de Beaufort, 1913, Fishes IndoAustr. Arch., 2: 61.

Dorsal iii-iv,13-15 (mean of branched rays $14.3 \pm 0.3 ; \mathrm{N}=7$ ); pectoral i,15-16 (mean i,15.0 $\pm 0.3 ; \mathrm{N}=6$ ); ventral $\mathrm{i}, 7$; anal 16-18 (mean $17.2 \pm 0.3 ; \mathrm{N}=6$ ); gill rakers $28-33$ (mean $30.6 \pm 0.7 ; \mathrm{N}=7$ ); mid-lateral scales 39-43; preventral scutes 10-16 (mean $13.4 \pm 0.8$; $\mathrm{N}=7$ ); postventral scutes $10-13$ (mean $12.0 \pm 0.5 ; \mathrm{N}=7$ ); total length 46-111 mm.; standard length 36.5-86.5 mm.; head 3.33-3.41; depth 3.58-3.80.

Pulo Bakkungaan Kechil. Beach (31).

\section{ENGRAULIDAE}

\section{Thrissocles baelama Forskål}

Clupea baelama Forskål, 1775, Descr. Anim., p. 72-Djedda, Red Sea.

Thrissocles baelama Fowler, 1934, Proc. Acad. Nat. Sci. Phila., 86: 69.

Engraulis baelama Weber and de Beaufort, 1913, Fishes Indo-Austr. Arch., 2: 32 .

Dorsal 13-15 (mean 14.4 $\pm 0.3 ; \mathrm{N}=7$ ); pectoral 13-14 (mean $13.3 \pm 0.2 ; \mathrm{N}=6$ ); ventral $\mathrm{i}, 6$; anal $29-34$ (mean $31.6 \pm 0.6 ; \mathrm{N}=7$ ); gill rakers 19 ; preventral scutes $4-5$ (mean $4.7 \pm 0.2 ; \mathrm{N}=6$ ); postventral scutes $8-10$ (mean $9.0 \pm 0.3 ; \mathrm{N}=6$ ); total length $32-41 \mathrm{~mm}$.; standard length 27.3-32.5 mm.; head 3.36-3.37; depth 4.48-4.59.

Pulo Bakkungaan Kechil. Reef (1) and beach (14).

\section{APODES}

\section{OPHICHTHYIDAE}

\section{*Leiuranus semicinctus Lay and Bennett}

Ophisurus semicinctus Lay and Bennett, 1836, Zool. Capt. Beechey's Voy., p. 66, pl. 20, fig. 4-Oahu. 
Liuranus semicinctus Günther, 1870, Cat. Fishes Brit. Mus., 7 : 54.

Leiuranus semicinctus Weber and de Beaufort, 1916, Fishes Indo-Austr. Arch., 3: 294, fig. 137.

Dark rings 21-28 (mean $24.5 \pm 1.2 ; \mathrm{N}=6$ ); total length $100-502$ mm.; snout-vent in total 1.89-2.11 (mean $2.01 \pm 0.04 ; \mathrm{N}=6$ ); depth in three largest $37.7-45.2$.

Ratio of head in total length varies with size in the following manner (total length in parentheses) : 13.04 (502), 12.64 (407), 12.07 (262), 11.88 (120), 10.97 (113), 10.30 (100).

The ventral extension of the black rings increases with size. In the three smallest specimens, the black pigment occupies only the upper half of the body. The second and third last rings extend across the ventral surface in the $262 \mathrm{~mm}$. individual. All postanal rings cross the ventrum in the next larger specimen, whereas all rings except the first three behind the head cross the belly of the largest individual.

Pulo Bakkungaan Kechil. Reef (3) and beach (3 smallest).

\section{MURAENIDAE}

\section{*Echidna delicatula Kaup}

Poecilophis delicatulus Kaup, 1856, Cat. Apod. Fish Brit. Mus., p. $102-$ Moluccas.

Echidna delicatula Bleeker, 1864, Atlas Ichthy., 4: 78, pl. 167, fig. 3; Weber and de Beaufort, 1916, Fishes Indo-Austr. Arch., 3: 350.

Total length $327 \mathrm{~mm}$; snout-vent in total 2.44; head in total 8.89; depth in total 15.87; gape in head 3.23.

Pulo Bakkungaan Kechil. Reef (1).

\section{*Echidna leucotaenia Schultz}

Echidna leucotaenia Schultz, 1943, Bull. U. S. Nat. Mus., no. 180, p. 22, pl. 3-Enderbury Island.

Total length $53 \mathrm{~mm}$.; snout-vent in total 1.63; head in total 6.80 ; depth in total 19.65 .

In coloration this juvenile agrees almost perfectly with the description of a $44 \mathrm{~mm}$. paratype (Schultz, 1943, p. 23). The snoutvent proportion differs from that given by Schultz for a $200 \mathrm{~mm}$. specimen (2.36).

Pulo Bakkungaan Kechil. Beach (1).

This is the first record of leucotaenia in the East Indies. 


\section{*Echidna nebulosa Ahl}

Muraena nebulosa Ahl, 1789, Spec. Ichthy. Muraena Ophichto, p. 7, pl. 1East Indies.

Echidna nebulosa Fowler, 1900, Proc. Acad. Nat. Sci. Phila., 1900: 524; Weber and de Beaufort, 1916, Fishes Indo-Austr. Arch., 3: 348, fig. 170.

Total length 84-124 mm.; snout-vent in total 1.95-2.00; head in total 8.00-8.62; gape in head 3.00-3.28.

Pulo Bakkungaan Kechil. Beach (2).

*Echidna polyzona Richardson

Muraena polyzona Richardson, 1844, Voy. Sulphur, Fishes, p. 112, pl. 55, figs. 11-14-no locality.

Echidna polyzona Bleeker, 1864, Atlas Ichthy., 4: 81, pl. 168, fig. 3; Weber and de Beaufort, 1916, Fishes Indo-Austr. Arch., 3: 346, fig. 169.

Total length $207 \mathrm{~mm}$.; snout-vent in total 2.18; head in total 7.14; gape in head 2.59; white rings 25.

Pulo Bakkungaan Kechil. Reef (1).

\section{*Echidna zebra Shaw}

Gymnothorax zebra Shaw, 1797, Nat. Misc., 9: pl. 322-American seas (in error).

Echidna zebra Bleeker, 1864, Atlas Ichthy., 4: 81, pl. 171, fig. 1; Weber and de Beaufort, 1916, Fishes Indo-Austr. Arch., 3: 345, fig. 168.

Total length $620 \mathrm{~mm}$; snout-vent in total 1.47; head in total 9.70; depth in total 18.62; gape in head 2.83.

Pulo Bakkungaan Kechil. Reef (1).

\section{*Gymnothorax buroensis Bleeker}

Muraena buroensis Bleeker, 1857, Nat. Tijd. Ned. Indië, 13: 79-Kajeli, Buru. Gymnothorax buroensis Bleeker, 1864, Atlas Ichthy., 4: 90, pl. 190, fig. 1.

Muraena (Gymnothorax) meleagris Weber and de Beaufort, 1916, Fishes Indo-Austr. Arch., 3: 367 (part).

Total length 50-300 mm.; snout-vent in total 2.02-2.08; head in total 6.50-8.32; depth in total 9.13-11.81; gape in head 2.23-2.93.

The two smallest specimens $(50 \mathrm{~mm} ., 133 \mathrm{~mm}$.) are uniform dark brown except for pale areas on the chin and throat. Their identification is uncertain.

Pulo Bakkungaan Kechil. Reef (5).

\section{*Gymnothorax chilospilus Bleeker}

Gymnothorax chilospilus Bleeker, 1865, Ned. Tijd. Dierk., 2: 52-Sumatra, Amboina, Ceram, and Buru. 
Muraena (Gymnothorax) chilospilus Weber and de Beaufort, 1916, Fishes Indo-Austr. Arch., 3: 379, fig. 188.

Total length $82-259 \mathrm{~mm}$; snout-vent in total 2.00-2.32 (mean $2.11 \pm 0.02 ; \mathrm{N}=18$ ); head in total 7.04-8.27 (mean $7.74 \pm 0.20 ; \mathrm{N}=6$;) gape in head 2.24-2.71 (mean $2.57 \pm 0.08 ; \mathrm{N}=6$ ).

Pulo Bakkungaan Kechil. Reef (19) and beach (2; 82-101 mm.).

\section{Gymnothorax fimbriatus Bennett}

Muraena fimbriata Bennett, 1831, Proc. Zool. Soc. London, 1830-31: 168Mauritius.

Gymnothorax fimbriatus Bleeker, 1873, Versl. Akad. Wetens. Amsterdam, (2), $7: 37$.

Muraena (Gymnothorax) undulata var. fimbriata Weber and de Beaufort, 1916, Fishes Indo-Austr. Arch., 3: 376, fig. 186.

Total length 91-642 mm.; snout-vent in total 2.04-2.26 (mean $2.16 \pm 0.03 ; \mathrm{N}=9$ ); head in total $6.48-7.35$ (mean $6.86 \pm 0.10 ; \mathrm{N}=8$ ); gape in head 2.10-2.43 (mean 2.28 $\pm 0.05 ; \mathrm{N}=7$ ).

One specimen $(278 \mathrm{~mm}$.) had a Halichoeres (head $18.5 \mathrm{~mm}$.) in the gut, a second (554 mm.) a Scorpaenodes (head $23 \mathrm{~mm}$.), and a third $(160 \mathrm{~mm}$.) a blennioid (head $9.0 \mathrm{~mm}$.).

Pulo Bakkungaan Kechil. Reef (7; 157-642 mm.) and beach (3; 91-161 mm.).

Pulo Nunuyan Laut $(2 ; 274-303 \mathrm{~mm}$.$) .$

\section{*Gymnothorax flavimarginatus Rüppell}

Muraena flavimarginata Rüppell, 1828, Atlas Reise nördl. Afrika, Fische, p. 119, pl. 30, fig. 3-Red Sea.

Gymnothorax flavimarginatus Bleeker, 1864, Atlas Ichthy., 4: 95, pl. 178, fig. 3.

Muraena (Gymnothorax) flavimarginata Weber and de Beaufort, 1916, Fishes Indo-Austr. Arch., 3: 374 (part).

Total length 197-410 mm.; snout-vent in total 2.04-2.16; head in total 8.04-8.95; depth in total 16.94-19.40; gape in head 2.09-2.38.

Pulo Bakkungaan Kechil. Reef (4).

\section{*Gymnothorax hepaticus Rüppell}

Muraena hepatica Rüppell, 1828, Atlas Reise nördl. Afrika, Fische, p. 120Red Sea.

Gymnothorax hepaticus Weber, 1913, Fische Siboga Exp., p. 57.

Muraena (Gymnothorax) hepatica Weber and de Beaufort, 1916, Fishes IndoAustr. Arch., 3: 385. 
Total length 139.5-310 mm.; snout-vent in total 1.90-1.94; head in total 10.02-10.33; depth in total 28.18-28.30; gape in head 2.53-2.59.

Pulo Bakkungaan Kechil. Reef (2) and beach (1; $190.5 \mathrm{~mm}$.$) .$

*Gymnothorax javanicus Bleeker

Muraena javanica Bleeker, 1859, Nat. Tijd. Ned. Indië, 19: 347-Java.

Gymnothorax javanicus Bleeker, 1864, Atlas Ichthy., 4: 95, pl. 179, fig. 2.

Muraena (Gymnothorax) flavimarginata Weber and de Beaufort, 1916, Fishes Indo-Austr. Arch., 3: 374 (part).

Total length 456-635 mm.; snout-vent in total 2.05-2.08; head in total 7.52-8.00; depth in total 15.40; gape in head 2.31-2.39.

Pulo Bakkungaan Kechil. Reef (2).

\section{Gymnothorax ruppelli McClelland}

Dalophis ruppelliae McClelland, 1845, Calcutta Jour. Nat. Hist., 5: 213 (on Rüppell's $M$. recticulata)-Red Sea.

Gymnothorax ruppelliae Kendall and Goldsborough, 1911, Mem. Mus. Comp. Zool., 26: 247.

Muraena (Gymnothorax) ruppelli Weber and de Beaufort, 1916, Fishes IndoAustr. Arch., 3: 372.

Total length $167 \mathrm{~mm}$.; snout-vent in total 2.35; head in total 8.07; gape in head 2.46; black rings 17 .

Pulo Bakkungaan Kechil. Reef (1).

\section{Gymnothorax undulatus Lacépède}

Muraenophis undulatus Lacépède, 1803, Hist. Nat. Poissons, 5: 629, 644, pl. 64, fig. 2-no locality.

Gymnothorax undulatus Jenkins, 1903, Bull. U. S. Fish Comm., 22: 426.

Muraena (Gymnothorax) undulatus Weber and de Beaufort, 1916, Fishes IndoAustr. Arch., 3: 376 (part).

Total length 248-276 mm.; snout-vent in total 2.09-2.21; head in total 7.42-7.58; depth in total 20.14; gape in head 2.32-2.51.

Pulo Nunuyan Laut (2).

\section{OSTARIOPHYSI \\ PLOTOSIDAE}

\section{Paraplotosus albilabris Valenciennes}

Plotosus albilabris Valenciennes, in Cuvier and Valenciennes, 1840, Hist. Nat. Poissons, 15: 427-Batavia, Java. 
Paraplotosus albilabris Weber and de Beaufort, 1913, Fishes Indo-Austr. Arch., 2: 225, figs. 88-89.

Dorsal I,4-5-95-110; pectoral I,12-13; ventral 12; anal 90-100; total length 191-229 mm.; standard length 166-210 mm.; head 4.78-5.46; depth 7.10-8.20.

Pulo Nunuyan Laut (3).

\section{INIOMI \\ SYNODONTIDAE}

Saurida gracilis Quoy and Gaimard

Saurus gracilis Quoy and Gaimard, 1824, Voy. Uranie, Zool., p. 224-Hawaiian Islands.

Saurida gracilis Jenkins, 1903, Bull. U. S. Fish Comm., 22: 433; Weber and de Beaufort, 1913, Fishes Indo-Austr. Arch., 2: 143, fig. 53.

Dorsal ii,8-9; pectoral i,11-12; ventral i,8; anal ii,7-8; lateral line scales 47-51; predorsal scales 15-16; total length $44-136 \mathrm{~mm}$.; standard length 36.8-115 mm.; head 3.68-4.18; depth 5.72-7.48.

Pulo Bakkungaan Kechil. Beach (4).

\section{Synodus variegatus Lacépède}

Salmo variegatus Lacépède, 1803, Hist. Nat. Poissons, 5: 157, pl. 3, fig. 3Mauritius.

Synodus variegatus Seale, 1900, Occ. Pap. Bishop Mus., 1, no. 3, p. 63.

Saurus variegatus Weber and de Beaufort, 1913, Fishes Indo-Austr. Arch., 2: 147 .

Dorsal ii-iii,8-10 (mean of branched rays $9.5 \pm 0.2 ; \mathrm{N}=13$ ); pectoral i-ii,10-12 (mean of branched rays $10.8 \pm 0.2 ; \mathrm{N}=12$ ); ventral 1,7; anal $8-10$ (mean $8.8 \pm 0.2 ; N=13$ ); lateral line scales $57-60$ (mean $58.5 \pm 0.3 ; \mathrm{N}=13$ ); predorsal scales 18-21 (mean $19.3 \pm 0.3 ; \mathrm{N}=12$ ) ; total length 41-154 mm.; standard length 32.7$132 \mathrm{~mm}$.; head 3.47-3.93 (mean 3.69 $\pm 0.5 ; \mathrm{N}=7$ ); depth 4.96-6.37.

Pulo Bakkungaan Kechil. Reef (15; 40.2-132 mm.) and beach (8; 32.7-62.7 mm.).

\section{SYNENTOGNATHI HEMIRAMPHIDAE}

Hyporhamphus melanurus Valenciennes

Hemiramphus melanurus Valenciennes in Cuvier and Valenciennes, 1846, Hist. Nat. Poissons, 19: 42-Celebes. 
Hemirhamphus melanurus Weber and de Beaufort, 1922, Fishes Indo-Austr. Arch., 4: 151.

Hemiramphus gaimardi Valenciennes in Cuvier and Valenciennes, 1846, Hist. Nat. Poissons, 19: 36-Moluccas, New Guinea.

Hemirhamphus gaimardi Weber and de Beaufort, 1922, Fishes Indo-Austr. Arch., 4: 150.

Hemirhamphus unifasciatus Weber and de Beaufort, 1922, Fishes Indo-Austr. Arch., 4: 149.

The only differences between the original descriptions of melanurus and gaimardi involve the color of the caudal (black-tipped in the former, no statement for the latter) and the relative length of the beak (seven and one-third in the total length in melanurus, six in gaimardi).

The results of an examination of the types were supplied to me very generously by the late Dr. Léon Bertin of the Museum National d'Histoire Naturelle. Dr. Bertin wrote that none of the types have black-tipped caudals now. In my material only those specimens in which the color is well preserved over the entire body have blacktipped caudals. Presumably the color distinction between Valenciennes' forms was a matter of difference in preservation.

The characters upon which Weber and de Beaufort based their separation of these species are listed below. Data concerning the types were supplied by Dr. Bertin. The Sandakan series includes eleven specimens collected by Herre and seven by me at Sandakan and vicinity.

The wide range of variation in the absence of correlation between characters makes distinction between these forms impossible.

Weber and de Beaufort give the trunk-to-head ratio of unifasciatus as 3.2. This low figure is apparently the sole basis for their recognition of unifasciatus in the Indo-Australian region. But 3.2 is within the range of the Sandakan series of melanurus. Hyporhamphus unifasciatus Ranzani (type locality Brazil) probably does not occur in the western Pacific. Specimens of unifasciatus from the eastern Pacific have 20-25 gill rakers on the lower limbs of the first gill arch (Meek and Hildebrand, 1923). The gill rakers vary from 17 to 19 in the Sandakan series. Specimens from the western Pacific identified as unifasciatus are presumably melanurus.

The entire Sandakan series agrees with the characters of Hyporhamphus as listed by Miller (1945).

Off mouth of Mankala River (5). Sandakan Fish Market (2). 

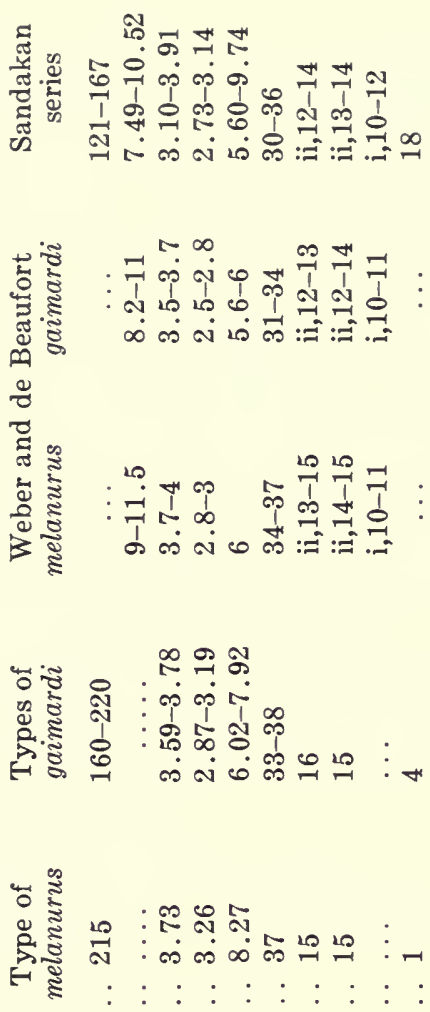


\section{HETEROSOMATA \\ BOTHIDAE}

*Bothus pantherinus Rüppell

Rhombus pantherinus Rüppell, 1828, Atlas Reise nördl. Afrika, Fische, p. 121, pl. 3, fig. 1-Mohila, Red Sea.

Bothus pantherinus Regan, 1920, Ann. Durban Mus., 2: 212, fig. 3.

Bothus (Platophrys) pantherinus Weber and de Beaufort, 1929, Fishes IndoAustr. Arch., 5: 123.

Dorsal 86-90; pectoral I,9; ventral 5-6; anal 65-69; lateral line scales 78-88; total length $65-141 \mathrm{~mm}$; standard length $53-116 \mathrm{~mm}$.; head 3.42-3.60; depth 1.74-1.86; upper jaw in head 2.90-3.10.

Pulo Bakkungaan Kechil. Reef (3; 66.5-141 mm.) and beach (1; $65 \mathrm{~mm}$.$) .$

\section{SOLEIDAE}

\section{*Pardachirus pavoninus Lacépède}

Achirus pavoninus Lacépède, 1802, Hist. Nat. Poissons, 4: 658-no locality.

Pardachirus pavoninus Günther, 1862, Cat. Fishes Brit. Mus., 4: 479; Weber and de Beaufort, 1929, Fishes Indo-Austr. Arch., 5: 165, fig. 46.

Dorsal 66-67; anal 52-53; ventral i,5; lateral line scales 84-88; total length $94-160.5 \mathrm{~mm}$.; standard length $79.5-138 \mathrm{~mm}$.; head 4.23-4.52; depth 2.09-2.12.

Pulo Bakkungaan Kechil. Reef (1).

Sandakan Fish Market (1).

\section{Solea heterorina Bleeker}

Solea heterorinos Bleeker, 1856, Acta Soc. Sci. Indo-Néerl., 1: 64-Amboina; Weber and de Beaufort, 1929, Fishes Indo-Austr. Arch., 5: 148, fig. 38.

Dorsal 96-98; pectoral 9; anal 81-84; lateral line scales 120-121; total length 91.5-124 mm.; standard length 81.5-110 mm.; head 5.79-5.95; depth 2.76-2.87.

Pulo Bakkungaan Kechil. Reef (3).

\section{BER YCOMORPHI \\ HOLOCENTRIDAE}

\section{*Holocentrus cornutus Bleeker}

Holocentrum cornutum Bleeker, 1853, Nat. Tijd. Ned. Indië, 5: 240-Ceram and Amboina; Weber and de Beaufort, 1929, Fishes Indo-Austr. Arch., 5: 243 , fig. 68 . 
Dorsal XI,13; pectoral ii,11; ventral I,7; anal IV,8-9; lateral line scales 34-36; total length 57.5-119 mm.; standard length 46.1-97.2 mm.; head 2.55-2.85; depth 2.63-2.70; eye 2.47-2.96.

Pulo Bakkungaan Kechil. Reef (4).

\section{*Holocentrus lacteoguttatus Cuvier}

Holocentrum lacteoguttatum Cuvier in Cuvier and Valenciennes, 1829, Hist. Nat. Poissons, 3: 214-East Indies; Weber and de Beaufort, 1929, Fishes Indo-Austr. Arch., 5: 240.

Dorsal XI,11; pectoral i,12; ventral I,7; anal IV,7; lateral line scales 38 ; total length $37 \mathrm{~mm}$.

Identification of this juvenile is uncertain. Despite the differences in soft anal rays and lateral line scales, this specimen fits the description of lacteoguttatum given by Weber and de Beaufort.

Pulo Bakkungaan Kechil. Reef (1).

\section{Holocentrus ruber Forskål}

Sciaena ruber Forskål, 1775, Descr. Anim., p. 48-Red Sea.

Holocentrus ruber Rüppell, 1828, Atlas Reise nördl. Afrika, Fische, p. 83.

Holocentrum rubrum Weber and de Beaufort, 1929, Fishes Indo-Austr. Arch., 5: 244 .

Dorsal XI,12-13 (mean XI,12.8 $\pm 0.2 ; \mathrm{N}=8$ ); pectoral ii,12; ventral I,7; anal IV,9; lateral line 34-35 (mean $34.3 \pm 0.2 ; \mathrm{N}=8$ ); total length 36-165 mm.; standard length $29.2-133 \mathrm{~mm}$.; head 2.40 2.59 (mean $2.52 \pm 0.03 ; \mathrm{N}=7$ ); depth 2.56-2.78 (mean 2.65 \pm 0.03 ; $\mathrm{N}=7$ ); eye 2.39-3.02 (mean $2.68 \pm 0.10 ; \mathrm{N}=6$ ).

Pulo Bakkungaan Kechil. Reef (8; 51.9-133 mm.) and beach (2; 29.2-29.5 mm.).

\section{*Holocentrus sammara Forskål}

Sciaena sammara Forskål, 1775, Descr. Anim., p. 48-Djedda, Red Sea. Holocentrus samara Rüppell, 1828, Atlas Reise nördl. Afrika, Fische, p. 85. Holocentrum sammara Weber and de Beaufort, 1929, Fishes Indo-Austr. Arch., 5: 233.

Dorsal X,i,12; pectoral ii,12; ventral I,7; anal IV,8; lateral line scales 39; total length $81 \mathrm{~mm}$.; standard length $64.7 \mathrm{~mm}$.; head 2.59; depth 3.18; eye 2.58.

Pulo Bakkungaan Kechil. Reef (1).

\section{Myripristis murdjan Forskål}

Sciaena murdjan Forskål, 1775, Descr. Anim., p. 48-Djedda, Red Sea. 
Myripristis murdjan Rüppell, 1828, Atlas Reise nördl. Afrika, Fische, p. 86;

Weber and de Beaufort, 1929, Fishes Indo-Austr. Arch., 5: 259.

Dorsal X,I,14; pectoral ii,13; ventral I,7; anal IV,8; lateral line scales 27; total length $71 \mathrm{~mm}$.; standard length $51.3 \mathrm{~mm}$.; head 2.38; depth 2.33; eye 2.16.

Pulo Bakkungaan Kechil. Reef (1).

\section{SOLENICHTHYES \\ SYNGNATHIDAE}

\section{*Ichthyocampus kampeni Weber}

Ichthyocampus kampeni Weber, 1913, Fische Siboga Exp., p. 114, fig. 40Karakelang, Salibabu, New Guinea, and Amboina; Weber and de Beaufort, 1922, Fishes Indo-Austr. Arch., 4: 93, fig. 38.

Dorsal 20-21; pectoral 12; anal 2; rings $16+29$; subdorsal rings $1+4$; total length $55.5-56.5 \mathrm{~mm}$.; standard length $54.5-55.0 \mathrm{~mm}$.; snout-vent in standard length 2.37-2.39; head 8.21-8.38.

Pulo Bakkungaan Kechil. Beach (2).

\section{FISTULARIIDAE}

Fistularia petimba Lacépède

Fistularia petimba Lacépède, 1803, Hist. Nat. Poissons, 5: 349-New Britain, Reunion, equatorial Pacific; Weber and de Beaufort, 1922, Fishes IndoAustr. Arch., $4: 14$, fig. 4.

Dorsal 14; pectoral 14; ventral i,5; anal 15; total length $176 \mathrm{~mm}$.; standard length $132 \mathrm{~mm}$.; snout in standard length 3.28.

Pulo Bakkungaan Kechil. Beach (1).

\section{PERCOIDEA}

\section{CARANGIDAE}

\section{Alectis ciliaris Bloch}

Zeus ciliaris Bloch, 1788, Ausländ. Fische, 6: 29, pl. 191-East Indies.

Alectis ciliaris Jordan and Evermann, 1905, Bull. U. S. Fish Comm., 23: 200, fig. 78; Weber and de Beaufort, 1931, Fishes Indo-Austr. Arch., 6: 269 .

Dorsal VI-I,18; pectoral ii,17; ventral I,5; anal II-I,16; total length $154 \mathrm{~mm}$.; standard length $122 \mathrm{~mm}$; head 2.72; depth 1.48; snout 2.22; eye 4.30 ; longest ventral filament $94 \mathrm{~mm}$.; longest dorsal filament $100+\mathrm{mm}$. 
Sandakan Fish Market (1). Reported from the south coast of Borneo as A. indicus (Weber and de Beaufort, 1931, p. 272).

\section{Caranx sexfasciatus Quoy and Gaimard}

Caranx sexfasciatus Quoy and Gaimard, 1824, Voy. Uranie, Zool., p. 358, pl. 65, fig. 4-New Guinea; Weber and de Beaufort, 1931, Fishes IndoAustr. Arch., 6: 243.

Dorsal (I) VIII-I,21; pectoral ii,18; ventral I,5; anal II-I,16; scutes 30 ; total length $96 \mathrm{~mm}$.; standard length $80 \mathrm{~mm}$.; head 3.07 ; depth 2.64 .

Off mouth of Mankala River (1).

\section{APOGONIDAE}

Apogon auritus Valenciennes

Apogon auritus Valenciennes in Cuvier and Valenciennes, 1831, Hist. Nat. Poissons, 7 : 443--Mauritius; Weber and de Beaufort, 1929, Fishes IndoAustr. Arch., 5: 325.

Dorsal VII-I,9; pectoral ii,11; ventral I,5; anal II,8; lateral line scales $22-23$ (mean $22.7 \pm 0.2 ; \mathrm{N}=10$ ); total length $55-66 \mathrm{~mm}$.; standard length 42.4-52.7 mm.; head 2.27-2.48 (mean 2.39 \pm 0.02 ; $\mathrm{N}=10$ ); depth 2.71-3.23 (mean $2.93 \pm 0.05 ; \mathrm{N}=10$ ).

Pulo Nunuyan Laut (53).

Pulo Bakkungaan Kechil. Reef (10).

\section{Apogon bandanensis Bleeker}

Apogon bandanensis Bleeker, 1854, Nat. Tijd. Ned. Indië, 6: 95-Banda Island; Weber and de Beaufort, 1929, Fishes Indo-Austr. Arch., 5: 317.

Dorsal VII-I,9; pectoral ii,11; ventral I,5; anal II,8; lateral line scales $23-25$ (mean $24.4 \pm 0.3 ; \mathrm{N}=7$ ) ; gill rakers (total) $23-27$ (mean $24.7 \pm 0.6 ; \mathrm{N}=6$ ); total length $24-64.5 \mathrm{~mm}$.; standard length 18.6-49.8 mm.; head 2.13-2.40 (mean $2.34 \pm 0.02 ; \mathrm{N}=8$ ); depth $2.36-2.63$ (mean $2.47 \pm 0.04 ; \mathrm{N}=8$ ).

The dark saddles are indistinct except for the well-marked one on the caudal peduncle.

Pulo Bakkungaan Kechil. Reef (13).

\section{*Apogon cardinalis Seale}

Amia cardinalis Seale, 1909, Philip. Jour. Sci., 4: 509-Puerta Princesa, Palawan. 
Dorsal VI-I,9; pectoral ii,11-12; anal II,7-8; lateral line scales 22 ; total length 25.5 $46 \mathrm{~mm}$; standard length $19.5-34.3 \mathrm{~mm}$.; head 2.45-2.56; depth 2.47-3.12.

Two gravid females (25.7-27.4 mm.).

Edges of the scales on the dorsal and ventral borders of the caudal peduncle are dusky. Otherwise these specimens are straw-colored and agree with the color notes of Fowler and Bean (1930).

Pulo Bakkungaan Kechil. Reef (6).

\section{Apogon ceramensis Bleeker}

Apogon ceramensis Bleeker, 1852, Nat. Tijd. Ned. Indië, 3: 256-Wahai, Ceram; Weber and de Beaufort, 1929, Fishes Indo-Austr. Arch., 5: 338.

Dorsal VI-1,9; pectoral ii,11-12; anal II,8; lateral line scales 23-25; total length 23-75 mm.; standard length $18.2-55.6 \mathrm{~mm}$.; head 2.18-2.52; depth 2.56-2.91; eye 2.79-3.58.

Identification of a specimen from Bakkungaan Kechil is uncertain. It lacks spots or streaks on the cheek and its black lateral line is much thinner than those of the other specimens.

Pulo Bakkungaan Kechil. Beach (1).

Pulo Nunuyan Laut (43).

Off mouth of Mankala River (3).

\section{Apogon endekataenia Bleeker}

Apogon endekataenia Bleeker, 1852, Nat. Tijd. Ned. Indië, 3: 449-Banka; Weber and de Beaufort, 1929, Fishes Indo-Austr. Arch., 5: 306.

Dorsal VII-1,9; pectoral ii,12-14 (mean ii,12.7 $\pm 0.3 ; \mathrm{N}=8$ ); anal II,8; lateral line scales 23-24 (mean $23.9 \pm 0.1 ; \mathrm{N}=7$ ); total length 18.5-61 mm.; standard length 14.6-47.8 mm.; head 2.37-2.66 (mean $2.50 \pm 0.04 ; \mathrm{N}=6$ ); depth 2.86-3.26 (mean $3.02 \pm 0.05 ; \mathrm{N}=8$ ); eye 2.52-3.00.

Pulo Bakkungaan Kechil. Reef $(5 ; 21.4-37.5 \mathrm{~mm}$.$) and beach$ (7).

Apogon fuscus Quoy and Gaimard

Apogon fuscus Quoy and Gaimard, 1824, Voy. Uranie, Zool., p. 345-Guam. Apogon chrysopomus Weber and de Beaufort, 1929, Fishes Indo-Austr. Arch., 5: 312 .

Dorsal VII-I,9; pectoral ii,12-13 (mean ii,12.1 $\pm 0.1 ; \mathrm{N}=9$ ); anal II,8; lateral line scales $24-25$ (mean $24.6 \pm 0.2 ; \mathrm{N}=9$ ); total 
length $87-120 \mathrm{~mm}$.; standard length $66.2-91.7 \mathrm{~mm}$.; head 2.52-2.67 (mean $2.60 \pm 0.02 ; \mathrm{N}=9$ ) ; depth $2.40-2.71$ (mean $2.59 \pm 0.04 ; \mathrm{N}=9$ ); eye 2.61-3.20.

Pulo Bakkungaan Kechil. Reef (9).

\section{Apogon margaritiphorus Bleeker}

Apogon margaritiphorus Bleeker, 1854, Nat. Tijd. Ned. Indië, 7: 363-Batjan;

Weber and de Beaufort, 1929, Fishes Indo-Austr. Arch., 5: 299.

Dorsal VII-I,9 (one specimen with 8 branched rays); pectoral ii,11; anal II,8 (one specimen with II,7); lateral line scales 23-25 (mean $23.8 \pm 0.2 ; \mathrm{N}=9$ ); total length 19-52.5 mm.; standard length 15.0-40.0 mm.; head 2.41-2.63 (mean 2.53 $\pm 0.03 ; \mathrm{N}=10$ ); depth 2.90-3.10 (mean $3.00 \pm 0.02 ; \mathrm{N}=10$ ).

Pulo Nunuyan Laut (153).

\section{Apogon multilineatus Bleeker}

Amia multilineata Bleeker, 1865, Ned. Tijd. Dierk., 2: 188-Ceram; 1873-76, Atlas Ichthy., $7: 83$, pl. 319, fig. 1.

Apogon multilineata Weber, 1913, Fische Siboga Exp., p. 223.

Apogon chrysotaenia Weber and de Beaufort, 1929, Fishes Indo-Austr. Arch., 5: 314 (part).

Dorsal VII-I,9; pectoral ii,11-12 (mean ii,11.9 $\pm 0.1 ; \mathrm{N}=10$ ); anal II,8; lateral line scales 24-25 (mean $24.1 \pm 0.1 ; \mathrm{N}=10$ ); scales between lateral line and anal origin 5-6; maximum total length $72 \mathrm{~mm}$.; standard length 40.4-55.4 mm.; head 2.43-2.75 (mean $2.59 \pm 0.03 ; \mathrm{N}=10$ ); depth 2.56-3.18 (mean 2.86 $\pm 0.05 ; \mathrm{N}=10$ ); eye 2.61-2.92.

In coloration this series agrees with Bleeker's description. Although Weber and de Beaufort synonymize multilineata with chrysotaenia Bleeker, the descriptions given by Bleeker (1873-76) adequately distinguish these two forms on the basis of coloration and body proportions.

Pulo Bakkungaan Kechil. Reef (12).

\section{*Apogon novemfasciatus Cuvier}

Apogon novemfasciatus Cuvier in Cuvier and Valenciennes, 1828, Hist. Nat.

Poissons, 2: 154-Timor and Guam; Weber and de Beaufort, 1929, Fishes Indo-Austr. Arch., 5: 302.

Dorsal VII-I,9; pectoral ii,12; anal II,8; lateral line scales 24-25; total length $47.5-53 \mathrm{~mm}$; ; standard length $36.6-41.4 \mathrm{~mm}$; head 2.43-2.54; depth 2.93-3.16. 
Weber and de Beaufort state that Indo-Australian specimens of endekataenia Bleeker always have a black spot on the caudal peduncle. This spot is conspicuously wider than the median tail stripe. No Indo-Australian specimen of novemfasciatus has this spot (Weber and de Beaufort, 1929). The three stripes on the caudal are conspicuous in novemfasciatus but are faint or absent in my series of endekataenia. When present in the latter, these stripes do not converge. Weber and de Beaufort find the tip of the first dorsal of novemfasciatus to be dusky. In the present sample, only a few scattered chromatophores are present, and these do not make the tip of the fin noticeably dark. By contrast the entire membrane between the first and second spines and the margin of the rest of the first dorsal of endekataenia are black.

Weber and de Beaufort also distinguish these two species on the basis of the narrower preorbital and more pointed snout of novemfasciatus. The cheek above the end of the maxilla is less than two-thirds the depth of the end of the maxilla in novemfasciatus, whereas cheek and maxilla are of subequal depths in endekataenia. The dorsal profile immediately before the orbit is concave in novemfasciatus and convex in endekataenia.

The interorbital of novemfasciatus is narrower than that of endekataenia. Slight differences in lateral line and pectoral rays may be seen in the counts and measurements given for the two species.

Pulo Bakkungaan Kechil. Reef (4).

\section{Apogon quadrifasciatus Cuvier}

Apogon quadrifasciatus Cuvier in Cuvier and Valenciennes, 1828, Hist. Nat. Poissons, 2: 153-Pondicherry, India; Weber and de Beaufort, 1929, Fishes Indo-Austr. Arch., 5: 300.

Apogon kiensis Herre, 1933, Jour. Pan-Pacific Res. Inst., 8, no. 4, p. 4 (not of Jordan and Snyder).

The only Bornean record of kiensis is given by Herre. His specimen (CNHM 22106), from Sandakan, has seven dorsal spines instead of the six found in kiensis Jordan and Snyder. In counts, coloration, and body proportion this specimen agrees with quadrifasciatus.

\section{Apogon trimaculatus Cuvier}

Apogon trimaculatus Cuvier in Cuvier and Valenciennes, 1828, Hist. Nat. Poissons, 2: 156, pl. 22-Buru; Weber and de Beaufort, 1929, Fishes Indo-Austr. Arch., 5: 335. 
Dorsal VI-I,9; pectoral ii,12-13 (mean ii,12.1 $\pm 0.1 ; \mathrm{N}=10$ ); anal II,8; lateral line scales 24-25 (mean $24.8 \pm 0.1 ; \mathrm{N}=10$ ); total length 23.5-147 mm.; standard length 17.5-115.4 mm.; head 2.43-2.61 (mean 2.53 $\pm 0.01 ; \mathrm{N}=10$ ); depth 2.52-2.69 (mean $2.61 \pm 0.02 ; \mathrm{N}=10)$; eye $3.34-3.63$.

A black opercular spot and a smaller spot at the end of the caudal peduncle are present in some individuals and absent in others. The dark band over the caudal peduncle mentioned by Weber and de Beaufort is absent in this series. In the two smallest specimens (17.5-25.5 mm.), the dark bands of the body are continuous between the dorsal and ventral profiles.

Pulo Bakkungaan Kechil. Reef (14).

\section{Paramia quinquelineata Cuvier}

Cheilodipterus quinquelineatus Cuvier in Cuvier and Valenciennes, 1828, Hist. Nat. Poissons, 2: 167-Society Islands; Weber and de Beaufort, 1929, Fishes Indo-Austr. Arch., 5 : 361.

Paramia quinquelineata Bleeker, 1865, Ned. Tijd. Dierk., 2: 147.

Dorsal VI-I,9; pectoral ii,10; anal II,8; total length 44-60 mm.; standard length 34.3-45.0 mm.; head 2.58-2.62; depth 3.60-4.07.

Pulo Bakkungaan Kechil. Reef (5).

\section{SILLAGINIDAE}

Sillago sihama Forskål

Atherina sihama Forskål, 1775, Descr. Anim., p. 70-Lohaja, Red Sea.

Sillago sihama Rüppell, 1825, Atlas Reise nördl. Afrika, Fische, p. 9, pl. 3,

fig. 1; Weber and de Beaufort, 1931, Fishes Indo-Austr. Arch., 6: 172,

fig. 33.

Dorsal XI-I,20-21; pectoral ii,14; ventral I,5; anal II,22-24; lateral line scales $68-70$; total length 104-129 mm.; standard length 89.0-114.0 mm.; head 3.24-3.47; depth 5.08-6.70.

Weber and de Beaufort are mistaken in stating that the opercular scales are cycloid. The present series and other specimens from various western Pacific localities have ctenoid opercular scales.

Off mouth of Mankala River (5).

Sandakan Fish Market (1).

\section{LEIOGNATHIDAE}

\section{Leiognathus fasciatus Lacépède}

Clupea fasciata Lacépède, 1803, Hist. Nat. Poissons, 5: 460-Mauritius. 
Leiognathus fasciatus Bleeker, 1863, Ned. Tijd. Dierk., 1: 242; Weber and de Beaufort, 1931, Fishes Indo-Austr. Arch., 6: 320.

Dorsal VIII,16; pectoral ii,16-18 (mean ii,17.1 $\pm 0.3 ; \mathrm{N}=7$ ); ventral I,5; anal III,14; lateral line pores 57-64 (mean 59.7 \pm 0.7 ; $\mathrm{N}=10$ ); total length $61-91 \mathrm{~mm}$.; standard length $47.1-70.1 \mathrm{~mm}$; head 2.70-2.85; depth 1.68-1.88.

Off mouth of Mankala River (33).

\section{GERRIDAE}

Gerres abbreviatus Bleeker

Gerres abbreviatus Bleeker, 1850, Verh. Bat. Gen., 23 (Maenidae), p. 11Batavia, Java; Weber and de Beaufort, 1931, Fishes Indo-Austr. Arch., 6: 344 .

- Dorsal IX,10; pectoral i-ii,13-14 (mean 13.7-0.2; $\mathrm{N}=7$ ); ventral I,5; anal III,7; lateral line scales $33-37$ (mean $35.5 \pm 0.4$; $\mathrm{N}=8$ ) ; total length $83-114 \mathrm{~mm}$.; standard length $62.7-87.0 \mathrm{~mm}$.; head 2.87-3.03 (mean 2.93 $\pm 0.02 ; \mathrm{N}=8$ ); depth 1.84-2.10 (mean $1.97 \pm 0.03 ; \mathrm{N}=8)$.

Off mouth of Mankala River (15).

\section{AMBASSIDAE}

\section{*Ambassis urotaenia}

Ambassis urotaenia Bleeker, 1852, Nat. Tijd. Ned. Indië, 3: 257-Amboina and Ceram; Weber and de Beaufort, 1929, Fishes Indo-Austr. Arch., 5: 404 .

Dorsal VII-I,9; pectoral ii,14; ventral I,5; anal III,9; lateral line scales 24-27; predorsal scales 8-9; total length 27-46 mm.; standard length 20.0-31.8 mm.; head 2.43-2.68; depth 2.67-2.94.

Pulo Bakkungaan Kechil. Beach (19).

\section{SERRANIDAE}

*Anyperodon leucogrammicus Valenciennes

Serranus leucogrammicus Valenciennes in Cuvier and Valenciennes, 1828, Hist. Nat. Poissons, 2: 347-Moluccas.

Anyperodon leucogrammicus Günther, 1859, Cat. Fishes Brit. Mus., 1: 96; Weber and de Beaufort, 1931, Fishes Indo-Austr. Arch., 6: 81, fig. 9.

Dorsal XI,16; pectoral ii,15; anal III,9; ventral I,5; scale rows crossing lateral line 82; total length $115 \mathrm{~mm}$; standard length $92.9 \mathrm{~mm}$.; head 2.34; depth 3.30 .

Pulo Bakkungaan Kechil. Reef (1). 
Cephalopholis cyanostigma Valenciennes

Serranus cyanostigma Valenciennes in Cuvier and Valenciennes, 1828, Hist. Nat. Poissons, 2: 359-Java.

Cephalopholis cyanostigma Fowler and Bean, 1930, Bull. U. S. Nat. Mus., no. $100,10: 223$.

Dorsal IX,15-17; pectoral i,15-16; ventral I,5; anal III,8; scale rows crossing lateral line 70-89; total length 125-204 mm.; standard length 106.4-167 mm.; head 2.37-2.42; depth 2.88-3.04; eye 5.76-6.97.

Pulo Bakkungaan Kechil. Reef (4).

Cephalopholis pachycentrum Valenciennes

Serranus pachycentron Valenciennes in Cuvier and Valenciennes, 1828, Hist.

Nat. Poissons, 2: 295-East Indies.

Epinephelus pachycentrum Boulenger, 1895, Cat. Fishes Brit. Mus., 2nd éd., 1: 178; Weber and de Beaufort, 1931, Fishes Indo-Austr. Arch., 6: 19.

Dorsal IX,15-16 (mean IX,15.2 $\pm 0.2 ; \mathrm{N}=6$ ); pectoral $\mathrm{i}, 15-16$ (mean $\mathrm{i}, 15.2 \pm 0.2 ; \mathrm{N}=6$ ); ventral I,5; anal III,8; scale rows crossing lateral line $62-70$ (mean $67.5 \pm 1.2 ; \mathrm{N}=6$ ); total length $58-130 \mathrm{~mm}$.; standard length 47.1-107 mm.; head 2.34-2.43 (mean 2.37 \pm 0.01 ; $\mathrm{N}=6)$; depth 2.59-2.91.

Pulo Bakkungaan Kechil. Reef (8).

\section{Epinephelus caeruleopunctatus Bloch}

Holocentrus caeruleopunctatus Bloch, 1790, Ausländ. Fische, 4: 94, pl. 241, fig. 2-no locality.

Epinephelus caeruleopunctatus Boulenger, 1895, Cat. Fishes Brit. Mus., 2nd ed., 1: 246; Weber and de Beaufort, 1931, Fishes Indo-Austr. Arch., 6: 66.

Dorsal XI,15-16; pectoral i-ii,14-16; ventral I,5; anal III,8; scale rows crossing lateral line 72 ; total length $45-102 \mathrm{~mm}$.; standard length 36.9-82.5 mm.; head 2.19-2.28; depth 3.18.

Pulo Bakkungaan Kechil. Reef (4) and beach (2;47.3-51.2 mm.).

\section{*Epinephelus corallicola Valenciennes}

Serranus corallicola Valenciennes in Cuvier and Valenciennes, 1828, Hist.

Nat. Poissons, 2: 336-no locality.

Epinephelus corallicola Bleeker, 1874, Verh. Akad. Wetens. Amsterdam, 14, no. 2, p. 83; Weber and de Beaufort, 1931, Fishes Indo-Austr. Arch., 6: 52.

Dorsal XI,15-16; pectoral ii,15-16; ventral I,5; anal III,8; scale rows crossing lateral line 69-76; total length $96-105 \mathrm{~mm}$; standard length 75.2-81.9 mm.; head 2.34-2.36; depth 3.07-3.15.

Pulo Nunuyan Laut (3). 


\section{Epinephelus fasciatus Forskål}

Perca fasciata Forskål, 1775, Descr. Anim., p. 40- Red Sea.

Epinephelus fasciatus Bleeker, 1874, Verh. Akad. Wetens. Amsterdam, 14, no. 2, p. 119; Weber and de Beaufort, 1931, Fishes Indo-Austr. Arch., 6: 58.

Dorsal XI,16; pectoral i,17-18; ventral I,5; anal III,8; scale rows crossing lateral line 89-90; total length 67-224 mm.; standard length 53.9-182 mm.; head 2.18-2.28; depth 2.94-2.97; eye 4.48-4.90.

Pulo Bakkungaan Kechil. Reef (6).

\section{*Epinephelus merra Bloch}

Epinephelus merra Bloch, 1793, Ausländ. Fische, 7 : 17, pl. 329-Sea of Japan;

Weber and de Beaufort, 1931, Fishes Indo-Austr. Arch., 6: 64.

Dorsal XI,15-19 (mean XI,17.1 $\pm 0.5 ; \mathrm{N}=7$ ); pectoral i,16-17 (mean $\mathrm{i}, 16.4 \pm 0.2 ; \mathrm{N}=7$ ); ventral I,5; anal III,8; scale rows crossing lateral line 88-104 (mean $97.4 \pm 2.1 ; \mathrm{N}=7$ ); total length $55-168 \mathrm{~mm}$.; standard length 43-136 mm.; head 2.28-2.37 (mean 2.33 \pm 0.01 ; $\mathrm{N}=7$ ); depth 2.93-3.15 (mean $3.05 \pm 0.03 ; \mathrm{N}=7$ ); eye $3.98-4.94$ (mean $4.49 \pm 0.11 ; \mathrm{N}=7$ ).

Pulo Bakkungaan Kechil. Reef $(2 ; 83-136 \mathrm{~mm}$.) and beach (2; 75-81 mm.).

Pulo Nunuyan Laut (3; 43-120 mm.).

\section{Epinephelus nebulosus Valenciennes}

Serranus nebulosus Valenciennes in Cuvier and Valenciennes, 1828, Hist. Nat. Poissons, 2: 313-no locality.

Epinephelus nebulosus Bleeker, 1874, Verh. Akad. Wetens. Amsterdam, 14, no. 2, p. 117; Weber and de Beaufort, 1931, Fishes Indo-Austr. Arch., 6: 57.

Dorsal XI,16; pectoral i,17; ventral I,5; anal III,8; scale rows crossing lateral line 77-78; total length 44.5-190 mm.; standard length 35.6-157 mm.; head 2.29-2.31; depth 3.09-3.23; eye 4.915.28 .

\section{Pulo Nunuyan Laut (3).}

\section{*Grammistes sexlineatus Thunberg}

Perca sexlineatus Thunberg, 1792, Vet. Akad. Handl. Stockholm, 13: 142, pl. 5-East Indies.

Grammistes sexlineatus Klunzinger, 1884, Fische Rothen Meeres, p. 10; Weber and de Beaufort, 1931, Fishes Indo-Austr. Arch., 62: 4, fig. 1.

Dorsal VI,15; pectoral i,15; ventral I,5; anal I,9; total length $32.7 \mathrm{~mm}$.; standard length $26.0 \mathrm{~mm}$.; head 2.60; depth 2.71 .

Pulo Bakkungaan Kechil. Reef (1). 


\section{CENTROPOMIDAE}

\section{Psammoperca waigiensis Cuvier}

Labrax waigiensis Cuvier in Cuvier and Valenciennes, 1828, Hist. Nat. Poissons, 2: 83-Waigeu.

Psammoperca waigiensis Bleeker, 1853, Nat. Tijd. Ned. Indië, 5: 177; Weber and de Beaufort, 1929, Fishes Indo-Austr. Arch., 5: 394, fig. 95.

Dorsal VII,12; pectoral i,13-14; ventral I,5; anal III,8; lateral line scales 43-46; total length 126-187 mm.; standard length 99$147 \mathrm{~mm}$.

Pulo Nunuyan Laut (3).

\section{PSEUDOCHROMIDAE}

\section{*Nematochromis annae Weber}

Nematochromis annae Weber, 1913, Fische Siboga Exp., p. 265, fig. 66Postillion Islands and Solor Strait; Weber and de Beaufort, 1931, Fishes Indo-Austr. Arch., 6: 138, fig. 25.

Dorsal II,xv,10; pectoral ii,16; ventral I,iii; anal II,viii,5; perforated scales in lateral line $23+12$; mid-lateral scales 34 ; total length $50 \mathrm{~mm}$.; standard length $39.0 \mathrm{~mm}$; head 3.02; depth 3.22 ; eye 3.58.

The second ventral ray, the largest, is slightly longer than the head and reaches the second soft anal ray. A pair of large interorbital pores is present.

This specimen differs from the original description only in the straight rather than convex head profile and in the lower number of scales in the upper lateral line (30 in the type). One or two missing scales on my specimen may account for part of the latter divergence.

Pulo Bakkungaan Kechil. Reef (1).

\section{*Plesiops coeruleolineatus Rüppell}

Plesiops coeruleolineatus Rüppell, 1835, Neue Wirbelth., Fische, p. 5, pl. 2, fig. 5-Massaua, Red Sea.

Plesiops melas Weber and de Beaufort, 1929, Fishes Indo-Austr. Arch., 5: 378, fig. 91 .

Dorsal XI,6-7 (mean XI,6.7 $\pm 0.2 ; \mathrm{N}=10$ ); pectoral i,20-22 (mean i,21.0 $\pm 0.3 ; \mathrm{N}=10$ ); ventral I,1,iii; anal III,7-8 (mean III, $7.9 \pm 0.1 ; \mathrm{N}=10$ ); lateral line scales $18-19+7-12$, total $25-31$ (mean total $28.0 \pm 0.6 ; \mathrm{N}=9$ ); mid-lateral scales 21-23 (mean $22.0 \pm 0.1 ; \mathrm{N}=10)$; total length $42-60.5 \mathrm{~mm}$; standard length 
32.6-45.2 mm.; head 2.48-2.59 (mean 2.54 $\pm 0.02 ; \mathrm{N}=6$ ); depth $3.05-3.37$ (mean $3.28 \pm 0.05 ; \mathrm{N}=6$ ).

The difference between the dorsal and anal counts of the present series on the one hand and those given by Weber and de Beaufort (dorsal XI,8; anal III,9) may reflect the different methods of counting the last ray on each fin.

Pulo Bakkungaan Kechil. Reef $(2 ; 32.6-45.2 \mathrm{~mm}$.) and beach $(13 ; 33.2-45.0 \mathrm{~mm}$.$) .$

\section{Pseudochromis fuscus Müller and Troschel}

Pseudochromis fuscus Müller and Troschel, 1849, Horae Ichthy., 3: 23, pl. 4, fig. 2-Celebes; Weber and de Beaufort, 1931, Fishes Indo-Austr. Arch., 6: 130 .

Dorsal III,24-26 (mean III,25.1 $\pm 0.3 ; \mathrm{N}=9$ ); pectoral ii,16-17 (mean ii,16.4 $\pm 0.2 ; \mathrm{N}=10$ ); ventral I,5; anal III,13-14 (mean III,13.8 $\pm 0.1 ; \mathrm{N}=10$ ); lateral line $27-31+8-11$, total $36-42$ (mean total $39.2 \pm 0.9 ; \mathrm{N}=6$ ); mid-lateral scales $36-41$ (mean $37.9 \pm 0.7$; $\mathrm{N}=7$ ); total length $40-72.5 \mathrm{~mm}$.; standard length $32.3-58.4 \mathrm{~mm}$.; head 2.75-3.24 (mean $3.07 \pm 0.05 ; \mathrm{N}=10$ ); depth 2.78-3.23 (mean $2.98 \pm 0.05 ; \mathrm{N}=8)$.

One female $(50.7 \mathrm{~mm}$.) was gravid. Depth in this specimen was 2.54.

Pulo Bakkungaan Kechil. Reef (7; 33.6-58.4 mm.).

Pulo Nunuyan Laut (2; 32.3-36.4 mm.).

\section{THERAPONIDAE}

\section{Pelates quadrilineatus Bloch}

Holocentrus quadrilineatus Bloch, 1793, Ausländ. Fische, 7: 63-the Orient. Pelates quadrilineatus Cuvier in Cuvier and Valenciennes, 1829, Hist. Nat. Poissons, 3: 146; Weber and de Beaufort, 1931, Fishes Indo-Austr. Arch., 6: 161 .

Dorsal XII,11; pectoral 15; ventral I,5; anal III,10; total length 24-27 mm.; standard length 17.0-20.5 mm.

Pulo Nunuyan Laut (2).

\section{Therapon jarbua Forskål}

Sciaena jarbua Forskål, 1775, Descr. Anim., p. 50-Red Sea.

Therapon jarbua Klunzinger, 1870, Verh. Zool. Bot. Ges. Wien, 20; 729;

Weber and de Beaufort, 1931, Fishes Indo-Austr. Arch., 6: 147, fig. 26 (5). 
Dorsal XII,9-10; pectoral ii,11; ventral I,5; anal III,8-9; scale rows crossing lateral line 68-72; total length 85-108 mm.; standard length 68.5-86.0 mm.; head 2.65; depth 2.65.

Pulo Nunuyan Laut (2).

\section{LUTIANIDAE}

\section{Lutianus decussatus Cuvier}

Mesoprion decussatus Cuvier in Cuvier and Valenciennes, 1828, Hist. Nat. Poissons, 2: 487-Java.

Lutjanus decussatus Bleeker, 1873, Verh. Akad. Wetens. Amsterdam, 13 (Lutjanus), p. 79; Weber and de Beaufort, 1936, Fishes Indo-Austr. Arch., 7: 285, fig. 61 .

Dorsal X,13; pectoral ii,14; ventral I,5; anal III,8; lateral line scales 49 ; total length $133-153 \mathrm{~mm}$; standard length 105.5-122 mm.; head 2.38-2.39; depth 2.60-2.71.

Pulo Bakkungaan Kechil. Reef (3).

\section{Lutianus janthinuropterus Bleeker}

Mesoprion janthinuropterus Bleeker, 1852, Nat. Tijd. Ned. Indië, 3: 751Bulucomba.

Lutjanus janthinuropterus Weber and de Beaufort, 1936, Fishes Indo-Austr. Arch., 7: 281.

Dorsal X,13; pectoral ii,15; ventral I,5; anal III,8; lateral line scales 53; total length $84 \mathrm{~mm}$.; standard length $68.4 \mathrm{~mm}$.; head 2.48 ; depth 2.69; eye 4.36.

Off mouth of Mankala River (1).

\section{Lutianus kasmira Forskål}

Sciaena kasmira Forskål, 1775, Descr. Anim., p. 46-Arabia.

Lutjanus kasmira Day, 1889, Fauna Brit. India, Fishes, 1: 468; Weber and de Beaufort, 1936, Fishes Indo-Austr. Arch., 7: 256.

Dorsal X,14; pectoral ii,14; ventral I,5; anal III,8; lateral line scales 51; total length $124 \mathrm{~mm}$.; standard length $98.9 \mathrm{~mm}$.; head 2.52; depth 2.80 .

Pulo Bakkungaan Kechil. Reef (1).

\section{*Lutianus russelli Bleeker}

Mesoprion russelli Bleeker, 1849, Verh. Bat. Gen., 22 (Perc.), p. 41-Vizagapatam, India. 
Lutjanus russelli Bleeker, 1873, Verh. Akad. Wetens. Amsterdam, 13 (Lutjanus), p. 76; Weber and de Beaufort, 1936, Fishes Indo-Austr. Arch., $7: 272$.

Dorsal X,14; pectoral ii,14; ventral I,5; anal III,8; lateral line scales 47 ; total length $57.5 \mathrm{~mm}$.; standard length $45.4 \mathrm{~mm}$.

Sandakan Fish Market (1).

Lethrinus miniatus (Forster) Bloch and Schneider

Sparus miniatus (Forster) Bloch and Schneider, 1801, Syst. Ichth., p. 281Pacific Ocean.

Lethrinus miniatus Valenciennes in Cuvier and Valenciennes, 1830, Hist. Nat. Poissons, 6: 296; Weber and de Beaufort, 1936, Fishes Indo-Austr. Arch., $7: 445$, fig. 89.

Dorsal X,9; pectoral ii,11; ventral I,5; anal III,8; lateral line scales 49 ; total length $148 \mathrm{~mm}$.; standard length $116.5 \mathrm{~mm}$.; head 2.39; depth 2.95; eye 4.44 .

Pulo Bakkungaan Kechil. Reef (1).

\section{Lethrinus ornatus Valenciennes}

Lethrinus ornatus Valenciennes in Cuvier and Valenciennes, 1830, Hist. Nat. Poissons, 6: 310_Java; Weber and de Beaufort, 1936, Fishes Indo-Austr. Arch., $7: 447$, fig. 90.

Dorsal X,9; pectoral ii,11; ventral I,5; anal III,8; lateral line scales 46-47; total length $27.5-125 \mathrm{~mm}$.; standard length 20.9-100.3 mm.; head 2.54-2.90; depth 2.42-2.73; eye 3.23-3.34.

Pulo Nunuyan Laut (7).

\section{*Pentapus caninus Cuvier}

Scolopsides caninus Cuvier in Cuvier and Valenciennes, 1830, Hist. Nat. Poissons, 5: 354-New Guinea.

Pentapus caninus Bleeker, 1873, Verh. Akad. Wetens. Amsterdam, 13 (Dentex), p. 61; Weber and de Beaufort, 1936, Fishes Indo-Austr. Arch., $7: 382$.

Dorsal X,9; pectoral ii,15; ventral I,5; anal III,7; lateral line scales $43-44$; total length $213-246 \mathrm{~mm}$.; standard length 167-192 mm.; head 3.12-3.20; depth 2.88-2.99.

Pulo Bakkungaan Kechil. Reef (2).

\section{Scolopsis ciliatus Lacépède}

Holocentrus ciliatus Lacépède, 1802, Hist. Nat. Poissons, 4: 333-no locality.

Scolopsis ciliatus Günther, 1859, Cat. Fishes Brit. Mus., 1: 355; Weber and de Beaufort, 1936, Fishes Indo-Austr. Arch., $7: 332$. 
Dorsal X,9; pectoral ii,14-15; ventral I,5; anal III,7; lateral line scales 40-42; total length 109.5-155 mm.; standard length 86.4-124 mm.; head 3.19-3.30; depth 2.70-3.03.

Pulo Bakkungaan Kechil. Reef (4; 98.0-124 mm.).

Pulo Nunuyan Laut (1).

\section{Scolopsis leucotaenia Bleeker}

Scolopsides leucotaenia Bleeker, 1852, Nat. Tijd. Ned. Indië, 3: 451-Banka or Lepar.

Scolopsis leucotaenia Günther, 1859, Cat. Fishes Brit. Mus,, 1: 363; Weber and de Beaufort, 1936, Fishes Indo-Austr. Arch., $7: 329$.

Dorsal X,9; pectoral ii,14; ventral I,5; anal III,7; lateral line scales 34-38; total length 59-65.5 mm.; standard length 45.9-51.0 mm.; head 2.92-2.98; depth 3.00-3.17.

Pulo Bakkungaan Kechil. Reef (2).

\section{Scolopsis margaritifer Cuvier}

Scolopsides margaritifer Cuvier in Cuvier and Valenciennes, 1830, Hist. Nat. Poissons, 5: 337-Waigeu.

Scolopsis margaritifer Günther, 1859, Cat. Fishes Brit. Mus., 1: 335; Weber and de Beaufort, 1936, Fishes Indo-Austr. Arch., $7: 328$.

Dorsal X,9; pectoral ii,14; ventral I,5; anal III,7; lateral line scales $36-37$ (mean $36.8 \pm 0.2 ; \mathrm{N}=6$ ); total length $116-191 \mathrm{~mm}$.; standard length 90.7-149 mm.; head 2.93-3.07 (mean 2.98 \pm 0.02 ; $\mathrm{N}=6)$; depth 2.45-2.66.

Pulo Bakkungaan Kechil. Reef (6).

\section{Scolopsis trilineatus Kner}

Scolopsis trilineatus Kner, 1868, Sitzber. Akad. Wiss. Wien, 57:27, pl. 2, fig. 5 -Samoa; Weber and de Beaufort, 1936, Fishes Indo-Austr. Arch., 7 : 331.

Dorsal X,9; pectoral 16; ventral I,5; anal III,8; lateral line scales 44 ; total length $31 \mathrm{~mm}$.; standard length $24.7 \mathrm{~mm}$.; head 2.78; depth 3.21 .

A round black spot covers the lower half of the dorsal membrane between the second and fourth spines.

Pulo Bakkungaan Kechil. Beach (1).

\section{MULLIDAE}

Parupeneus barberinus Lacépède

Mullus barberinus Lacépède, 1802, Hist. Nat. Poissons, 3: 406, pl. 13, fig. 3 -Moluccas. 
Parupeneus barberinus Bleeker, 1863, Ned. Tijd. Dierk., 1: 234; Weber and de Beaufort, 1931, Fishes Indo-Austr. Arch., 6: 392, fig. 77.

Dorsal VIII-I,8; pectoral ii,15; ventral I,5; anal II,6; lateral line scales 29; total length $152 \mathrm{~mm}$.; standard length $118 \mathrm{~mm}$.; head 2.90; depth 3.36; eye 5.42 .

Pulo Bakkungaan Kechil. Reef (1).

\section{*Parupeneus malabaricus Cuvier}

Upeneus malabaricus Cuvier in Cuvier and Valenciennes, 1829, Hist. Nat. Poissons, 3: 467-Malabar.

Parupeneus malabaricus Weber, 1913, Fische Siboga Exp., p. 297; Weber and de Beaufort, 1931, Fishes Indo-Austr. Arch., 6: 395.

Dorsal VIII-I,8; pectoral ii,14-15; ventral I,5; anal II,6; lateral line scales 29; total length 41-199 mm.; standard length $32.4-154.5$ mm.; head 3.05-3.24; depth 3.38-3.57; eye 5.04-5.62.

Pulo Bakkungaan Kechil. Reef $(2 ; 134-154.5 \mathrm{~mm}$.$) and beach$ $(2 ; 32.4-34.9 \mathrm{~mm}$.).

\section{Upeneus tragula Richardson}

Upeneus tragula Richardson, 1845, Ichthy. China Japan, p. 220-Canton; Weber and de Beaufort, 1931, Fishes Indo-Austr. Arch., 6: 368, fig. 75.

Dorsal VIII-I,8; pectoral ii,11; ventral I,5; anal II,6; lateral line scales 30-31; total length $149 \mathrm{~mm}$; standard length $114.4-114.8$ mm.; head 3.47-3.62; depth 3.83-3.90; eye 3.87-4.29.

Pulo Bakkungaan Kechil. Reef (2).

\section{ZANCLIDAE}

\section{Zanclus cornutus Linnaeus}

Chaetodon cornutus Linnaeus, 1758, Syst. Nat., 10th ed., 1: 273-East Indies.

Zanclus cornutus Cuvier in Cuvier and Valenciennes, 1831, Hist. Nat. Poissons, 7: 102; Weber and de Beaufort, 1936, Fishes Indo-Austr. Arch., 7: 170, figs. 43-44.

Dorsal VII,41-42; pectoral ii,16; ventral I,5; anal III,34; total length 73-80 mm.; standard length 56.5-57.8 mm.; head 2.12-2.21.

Pulo Bakkungaan Kechil. Reef (2).

\section{GHAETODONTIDAE}

\section{Chaetodon auriga Forskål}

Chaetodon auriga Forskål, 1775, Descr. Anim., p. 60-Djedda and Lohaja, Red Sea. 
Anisochaetodon auriga Weber and de Beaufort, 1936, Fishes Indo-Austr. Arch., 7: 103.

Dorsal XIII,22-23; pectoral ii,14; ventral I,5; anal III,20; total length 27-41.5 mm.; standard length 21.8-35.1 mm.; head 2.44; depth 1.80 .

Pulo Bakkungaan Kechil. Reef (2).

\section{Chaetodon lunula Lacépède}

Pomacentrus lunula Lacépède, 1803, Hist. Nat. Poissons, 4: 507-no locality.

Chaetodon lunula Cuvier in Cuvier and Valenciennes, 1831, Hist. Nat. Poissons, 7: 59; Weber and de Beaufort, 1936, Fishes Indo-Austr. Arch., 7: 83.

Dorsal XII,25; pectoral ii,13; ventral I,5; anal III,19; total length $25 \mathrm{~mm}$.; standard length $18.8 \mathrm{~mm}$.

Identical in coloration with Günther's illustration (pl. 33, fig. c, Fische der Südsee, 1: 420).

Pulo Bakkungaan Kechil. Reef (1).

\section{*Chaetodon rafflesi Bennett}

Chaetodon rafflesi Bennett, 1830, Life of Raffles, p. 689-Sumatra.

Anisochaetodon rafflesi Weber and de Beaufort, 1936, Fishes Indo-Austr. Arch., $7: 109$.

Dorsal XIII,21; pectoral ii,14; ventral I,5; anal III,19; midlateral scales 27 ; total length $22.5-100 \mathrm{~mm}$.; standard length 18.0 $85.0 \mathrm{~mm}$.; head 2.88 .

Pulo Bakkungaan Kechil. Reef (5).

\section{*Chaetodon vagabundus Linnaeus}

Chaetodon vagabundus Linnaeus, 1758, Syst. Nat., 10th ed., 1: 276-East Indies.

Anisochaetodon vagabundus Weber and de Beaufort, 1936, Fishes Indo-Austr. Arch., 7: 106.

Dorsal XIII,22-24; pectoral ii,14; ventral I,5; anal III,19-20; mid-lateral scales 31 ; total length 19-50 mm.; standard length 15-41 mm.; head 2.61; depth 1.70 (head and depth of largest specimen).

Pulo Bakkungaan Kechil. Reef $(5 ; 15.7-22.2 \mathrm{~mm}$.$) and beach$ (4).

\section{ACANTHURIDAE}

\section{*Acanthurus chrysosoma Bleeker}

Acanthurus chrysosoma Bleeker, 1857, Nat. Tijd. Ned. Indie, 13: 67-Kajeli, Buru; de Beaufort, 1951, Fishes Indo-Austr. Arch., 9: 165. 
Dorsal IX,26; pectoral I,16; ventral I,5; anal III,24; total length $47 \mathrm{~mm}$.; standard length $38.4 \mathrm{~mm}$.; head 2.93; depth 2.14 .

In coloration this specimen differs from chrysosoma in the presence of a thin oblique blue line that runs from behind the pectoral base to the vent. The head ratio is smaller than that given by de Beaufort for chrysosoma.

Pulo Bakkungaan Kechil. Beach (1).

\section{Acanthurus matoides Valenciennes}

Acanthurus matoides Valenciennes in Cuvier and Valenciennes, 1835, Hist. Nat. Poissons, 10: 204-Oualan; de Beaufort, 1951, Fishes Indo-Austr. Arch., 9: 156.

Dorsal IX,25-26; pectoral I,15-16; ventral I,5; anal III,22-24; total length $29.5-38 \mathrm{~mm}$.; standard length $22.6-26.2 \mathrm{~mm}$.

Identification of these juveniles is tentative.

Pulo Bakkungaan Kechil. Reef (3) and beach (5).

\section{Ctenochaetus strigosus Bennett}

Acanthurus strigosus Bennett, 1828, Zool. Jour., 4: 41-Hawaiian Islands.

Ctenochaetus strigosus Seale, 1901, Occ. Pap. Bishop Mus., 1: 109; de Beaufort, 1951, Fishes Indo-Austr. Arch., 9: 128, fig. 24.

Dorsal VIII,26; pectoral I,i,14; ventral I,5; anal III,25; total length $39.5 \mathrm{~mm}$.; standard length $30.5 \mathrm{~mm}$.; head 2.85; depth 1.86.

Pulo Bakkungaan Kechil. Beach (1).

\section{SIGANIDAE}

Siganus oramin Bloch and Schneider

Amphacanthus guttatus var. oramin Bloch and Schneider, 1801, Syst. Ichthy., p. 207, pl. 47-Tranquebar, India.

Siganus oramin Jordan and Richardson, 1908, Bull. U. S. Bur. Fish., 27: 271; de Beaufort, 1951, Fishes Indo-Austr. Arch., 9: 107.

Dorsal XIII,10; pectoral ii,14; ventral I,3,I; anal VII,9; total length $205 \mathrm{~mm}$.; standard length $161 \mathrm{~mm}$.; head 3.92; depth 2.51.

Pulo Bakkungaan Kechil. Reef (1).

Siganus virgatus Valenciennes

Amphacanthus virgatus Valenciennes in Cuvier and Valenciennes, 1835, Hist. Nat. Poissons, 10: 133-Java.

Siganus virgatus Jordan and Fowler, 1902, Proc. U. S. Nat. Mus., 25: 562; de Beaufort, 1951, Fishes Indo-Austr. Arch., 9: 113. 
Dorsal XIII,10; pectoral ii,14-15 (mean ii,14.5 $\pm 0.2 ; \mathrm{N}=10$ ); ventral I,3,I; anal VII,9; total length $34-157.5 \mathrm{~mm}$.; standard length 27.8-125 mm.; head 3.15-3.57 (mean $3.34 \pm 0.04 ; \mathrm{N}=10$ ); depth 1.88-2.08 (mean $1.97 \pm 0.02 ; \mathrm{N}=10$ ).

Pulo Bakkungaan Kechil. Reef (3; 100.8-125 mm.).

Pulo Nunuyan Laut (24; $27.8-114.8 \mathrm{~mm}$.$) .$

\section{PERCESOCES}

\section{ATHERINIDAE}

\section{Allanetta forskali Rüppell}

Atherina forskalii Rüppell, 1835, Neue Wirbelth., Fische, p. 132, pl. 33, fig. 1-Red Sea; Weber and de Beaufort, 1922, Fishes Indo-Austr. Arch., 4: 274 .

Dorsal V-II,7-8; pectoral i,14-15; ventral I,5; anal II,10-12; lateral line scales $41-42$; total length $28-68.5 \mathrm{~mm}$.; standard length 22.5-57.1 mm.; head 3.65-3.83; depth 4.92-6.20.

Pulo Bakkungaan Kechil. Reef (2) and beach (2; 40.5-49.7 $\mathrm{mm}$.$) .$

\section{Allanetta duodecimalis Valenciennes}

Atherina duodecimalis Valenciennes in Cuvier and Valenciennes, 1835, Hist.

Nat. Poissons, 10: 458-Ceylon; Weber and de Beaufort, 1922, Fishes

Indo-Austr. Arch., $4: 275$.

Allanetta duodecimalis Schultz, 1948, Proc. U. S. Nat. Mus., 98: 23.

Dorsal V-II,8; pectoral i,13; ventral I,5; anal II,10; lateral line scales 36 ; total length $66 \mathrm{~mm}$.; standard length $53.7 \mathrm{~mm}$.; head 3.29; depth 4.26.

Sandakan Fish Market (1).

\section{SPHYRAENIDAE}

Sphyraena barracuda Walbaum

Esox barracuda Walbaum, 1792, Artedi Gen. Pisc., 3: 94-West Indies.

Sphyraena barracuda Jordan and Evermann, 1898, Bull. U. S. Nat. Mus., no. 47 , p. 2841.

Sphyraena picuda Weber and de Beaufort, 1922, Fishes Indo-Austr. Arch., 4: 224 .

Dorsal v-ii,8; pectoral ii,12; ventral I,5; anal iii,7; lateral line scales 78; total length $223 \mathrm{~mm}$.; standard length $184 \mathrm{~mm}$.; head 3.05; depth 6.67; eye 6.15.

Sandakan Fish Market (1). 


\section{Sphyraena obtusata Cuvier}

Sphyraena obtusata Cuvier in Cuvier and Valenciennes, 1829, Hist. Nat. Poissons, 3: 350-Pondicherry, India; Weber and de Beaufort, 1922,

Fishes Indo-Austr. Arch., $4: 226$.

Dorsal v-ii,8; pectoral ii,12-13; ventral I,5; anal iii,8; lateral line scales 79-84; total length 204-219 mm.; standard length 170-186 $\mathrm{mm}$.; head 2.92-2.96; depth 6.75-7.36; eye 4.80-5.02.

Sandakan Fish Market (2).

\section{CATAPHRACTI \\ SCORPAENIDAE}

\section{*Amblyapistus taenianotus Cuvier}

Apistus taenianotus Cuvier in Cuvier and Valenciennes, 1829, Hist. Nat. Poissons, 4 : 404-no locality.

Amblyapistus taenianotus Bleeker, 1874, Rech. Faune Madagascar, pt. 4, p. 87.

Dorsal XVII,8; pectoral i,10; ventral I,3/4; anal III,5; lateral line pores 22 ; total length $68 \mathrm{~mm}$.; standard length $49.9 \mathrm{~mm}$.; head 2.85; depth 2.67 .

Pulo Bakkungaan Kechil. Reef (1).

\section{Scorpaena picta Cuvier}

Scorpaena picta Cuvier in Cuvier and Valenciennes, 1829, Hist. Nat. Poissons, 4: 236 -Java.

Dorsal XI-I,9; pectoral i,4-5,xi-xii, total rays $16-17$ (mean total $16.9 \pm 0.1 ; \mathrm{N}=10$ ); ventral I,5 (one specimen I,5/4); anal III,5; scale rows crossing lateral line $39-44$ (mean $41.3 \pm 0.1 ; \mathrm{N}=10$ ); total length 31-141 mm.; standard length 24.2-108.0 mm.; head 1.98-2.29 (mean $2.16 \pm 0.03 ; \mathrm{N}=10$ ); depth 2.38-2.78 (mean $2.62 \pm$ $0.04 ; \mathrm{N}=10$ ); eye $3.53-4.86$ (mean $4.18 \pm 0.15 ; \mathrm{N}=9$ ).

Pulo Bakkungaan Kechil. Reef (7; 45.4-108 mm.) and beach (2; 85.6-98.5 mm.).

Pulo Nunuyan Laut $(10 ; 24.2-81.0 \mathrm{~mm}$.$) .$

\section{*Scorpaenodes guamensis Quoy and Gaimard}

Scorpaena guamensis Quoy and Gaimard, 1824, Voy. Uranie, Zool., p. 326Guam.

Scorpaenodes guamensis Fowler, 1928, Mem. Bishop Mus., 10: 289.

Dorsal XIII,8; pectoral i-ii,4-7,x-xii, total rays $16-19$ (mean total $17.9 \pm 0.3 ; \mathrm{N}=9$ ); ventral I,5; anal III,5; scale rows crossing lateral 
line 35-44 (mean 38.6 $\pm 0.9 ; \mathrm{N}=9$ ); total length $32-77 \mathrm{~mm}$.; standard length 28.5-60.8 mm.; head 2.12-2.27 (mean 2.20 \pm 0.02 ; $\mathrm{N}=8$ ); depth 2.49-2.77 (mean 2.62 $\pm 0.03 ; \mathrm{N}=8$ ).

Pulo Bakkungaan Kechil. Reef (10).

\section{*Scorpaenopsis gibbosus Bloch and Schneider}

Scorpaena gibbosus Bloch and Schneider, 1801, Syst. Ichthy., p. 192, pl. 44America (in error).

Scorpaenopsis gibbosus Bleeker, 1859, Acta Soc. Sci. Indo-Néerl., 6 (Enum. spec.), p. 40 , pl. 2 , fig. 1.

Dorsal XII,9; pectoral i,5,xii; ventral I,5; anal III,5; scale rows crossing lateral line 41-44; total length 175-185 mm.; standard length 135-153 mm.

Pulo Bakkungaan Kechil. Reef (2).

\section{*Sebastes stoliczkae Day}

Sebastes stoliczkae Day, 1878, Fishes India, pt. 1, p. 148, pl. 36, fig. 1-Nicobar Islands.

Dorsal XIV,10; pectoral i-ii,12-13; ventral I,5; anal III,5; lateral line scales 39-40; total length 75.5-107 mm.; standard length 59.4-84.6 mm.; head 2.25-2.30; depth 2.47-2.58; eye 3.40-3.67.

Pulo Bakkungaan Kechil. Reef (1).

Pulo Nunuyan Laut (1).

\section{CHROMIDES \\ POMAGENTRIDAE}

\section{*Abudefduf anabatoides Bleeker}

Glyphisodon anabatoides Bleeker, 1847, Verh. Bat. Gen., 21: 28-Java.

Abudefduf anabatoides Fowler and Bean, 1928, Bull. U. S. Nat. Mus., no. 100, 7: 183; de Beaufort, 1940, Fishes Indo-Austr. Arch., 8: 412.

Dorsal XIII,10-11; pectoral ii,15-17; ventral I,5; anal II,10-11; lateral line scales 20-21+8-13; mid-lateral scales 26-28; total length 74-83.5 mm.; standard length 55.3-61.1 mm.; head 3.36-3.49; depth 2.50-2.68.

De Beaufort gives the lateral line count as $17+10$. In my series there are 16-18 tubulated scales plus 3-4 scales having pores only in the upper part of the lateral line. Presumably de Beaufort's count includes only tubulated scales.

Pulo Bakkungaan Kechil. Reef (5). 


\section{Abudefduf biocellatus Quoy and Gaimard}

Glyphisodon biocellatus Quoy and Gaimard, 1824, Voy. Uranie, Zool., p. $389-$ Guam.

Abudefduf biocellatus Fowler and Bean, 1928, Bull. U. S. Nat. Mus., no. 100,

7: 166; de Beaufort, 1940, Fishes Indo-Austr. Arch., 8: 436 (part).

Dorsal XIII,13; pectoral ii,16; ventral I,5; anal II,13; lateral line scales $17+7$; mid-lateral scales 26 ; total length $51.5 \mathrm{~mm}$.; standard length $39.8 \mathrm{~mm}$.; head 2.95; depth 2.17.

Pulo Bakkungaan Kechil. Beach (1).

\section{Abudefduf curacao Bloch}

Chaetodon curacao Bloch, 1787, Ausländ. Fische, 3: 106, pl. 212, fig. 1Curacao Island (in error).

Abudefduf curacao Evermann and Seale, 1907, Bull. Bur. Fish., 26: 93; de Beaufort, 1940, Fishes Indo-Austr. Arch., 8: 414.

Dorsal XIII,11-12 (mean XIII,11.8 $\pm 0.1 ; \mathrm{N}=12$ ); pectoral ii,14-15 (mean ii,14.7 $\pm 0.1 ; \mathrm{N}=11$ ); ventral I,5; anal II,12-13 (mean II, $12.7 \pm 0.1 ; \mathrm{N}=11$ ); lateral line scales $20+8$; mid-lateral scales 25-26 (mean $25.3 \pm 0.1 ; \mathrm{N}=11$ ); total length $36.5-98 \mathrm{~mm}$.; standard length 26.7-71.4 mm.; head 3.02-3.18 (mean $3.12 \pm 0.01$; $\mathrm{N}=10$ ); depth 1.64-1.74 (mean $1.68 \pm 0.01 ; \mathrm{N}=10$ ).

Pulo Bakkungaan Kechil. Reef (23).

\section{Abudefduf lachrymatus Quoy and Gaimard}

Glyphisodon lachrymatus Quoy and Gaimard, 1824, Voy. Uranie, Zool., p. 388, pl. 62, fig. 7-Guam.

Abudefduf lachrymatus Jordan and Seale, 1906, Bull. Bur. Fish., 25: 258; de Beaufort, 1940, Fishes Indo-Austr. Arch., 8: 439.

Dorsal XII,16-18; (mean XII,16.5 \pm 0.2 ; pectoral ii,17-18 (mean ii,17.4 $\pm 0.2 ; \mathrm{N}=10$ ); ventral I,5; anal II,13-14 (mean II, $13.3 \pm 0.2 ; \mathrm{N}=10)$; lateral line scales $17-19+7-9$; mid-lateral scales 25-27 (mean $25.6 \pm 0.2 ; \mathrm{N}=10$ ); total length $60.5-87 \mathrm{~mm}$.; standard length $43.3-64.4 \mathrm{~mm}$; head $2.97-3.20$ (mean $3.08 \pm 0.02$; $\mathrm{N}=10$ ); depth 1.75-1.97 (mean $1.84 \pm 0.02 ; \mathrm{N}=10$ ).

Pulo Bakkungaan Kechil. Reef (11).

\section{*Abudefduf oxyodon Bleeker}

Glyphisodon oxyodon Bleeker, 1858, Acta Soc. Sci. Indo-Néerl., 3: 14-Manado, Celebes.

Abudefduf oxyodon Fowler and Bean, 1928, Bull. U. S. Nat. Mus., no. 100, 7: 164; de Beaufort, 1940, Fishes Indo-Austr. Arch., 8: 428. 
Dorsal XIII,12-13 (mean XIII,12.8 $\pm 0.2 ; \mathrm{N}=6$ ); pectoral ii,15-16 (mean ii,15.2 $\pm 0.2 ; \mathrm{N}=6$ ); ventral I,5; anal II,12-13 (mean II,12.8 $\pm 0.2 ; \mathrm{N}=6$ ); lateral line scales $17-18+6-9$; midlateral scales 25-27; total length 24-45 mm.; standard length 17.9-33.7 mm.; head 2.64-3.87 (mean 2.80 $\pm 0.03 ; \mathrm{N}=7$ ); depth $1.77-1.99$ (mean $1.89 \pm 0.03 ; \mathrm{N}=7$ ).

Pulo Bakkungaan Kechil. Reef (12).

\section{Abudefduf saxatilis Linnaeus}

Chaetodon saxatilis Linnaeus, 1758, Syst. Nat., 10th ed., 1:276-India. Abudefduf saxatilis Jordan and Seale, 1907, Bull. Bur. Fish., 26: 28.

Abudefduf saxatilis vaigiensis de Beaufort, 1940, Fishes Indo-Austr. Arch., 8: 404 .

Dorsal XIII,13-14 (mean XIII,13.1 $\pm 0.1 ; \mathrm{N}=8$ ); pectoral ii,15-17 (mean ii, $16.3 \pm 0.3 ; \mathrm{N}=8$ ); ventral I,5; anal II,12-14 (mean II,12.5 $\pm 0.3 ; \mathrm{N}=8$ ) ; mid-lateral scales $27-29$ (mean $27.6 \pm 0.3$; $\mathrm{N}=8$ ); total length $72-93 \mathrm{~mm}$.; standard length $51.3-65.8 \mathrm{~mm}$.; head 2.89-3.07 (mean 2.97 $\pm 0.03 ; \mathrm{N}=6$ ); depth 1.87-2.04 (mean $1.96 \pm 0.02 ; \mathrm{N}=6)$.

Pulo Bakkungaan Kechil. Reef (6).

Pulo Nunuyan Laut (2; 57.0-65 mm.).

\section{*Abudefduf sexfasciatus Lacépède}

Labrus sexfasciatus Lacépède, 1802, Hist. Nat. Poissons, 3: 430, pl. 19, fig. 2Indo-Pacific Ocean.

Abudefduf sexfasciatus Jordan and Snyder, 1901, Proc. U. S. Nat. Mus., 23: 755 .

Abudefduf coelestinus de Beaufort, 1940, Fishes Indo-Austr. Arch., 8: 409.

Dorsal XIII,12-13; pectoral ii,16-17; ventral I,5; anal II,12; mid-lateral scales 27 ; total length 17-122 mm.; standard length 13.0-88.8 mm.; head 3.16-3.21; depth 1.77-1.92.

Pulo Bakkungaan Kechil. Reef (4).

\section{Abudefduf uniocellatus Quoy and Gaimard}

Glyphisodon uniocellatus Quoy and Gaimard, 1824, Voy. Uranie, Zool., p. 393, pl. 64, fig. 4-Timor(?) and Mariannes.

Abudefduf uniocellatus Fowler and Bean, 1928, Bull. U. S. Nat. Mus., no. 100, $7: 173$.

Abudefduf assimilis de Beaufort, 1940, Fishes Indo-Austr. Arch., 8: 431.

Dorsal XIII,13-14 (mean XIII,13.1 $\pm 0.1 ; \mathrm{N}=10$ ); pectoral ii,16-17 (mean ii,16.3 $\pm 0.2 ; \mathrm{N}=10$ ); ventral I,5; anal II,12; lateral 
line scales 16-18+7-8; mid-lateral scales 25-27 (mean 25.7 \pm 0.2 ; $\mathrm{N}=10$ ); total length $27-71 \mathrm{~mm}$.; standard length $21.0-55.4 \mathrm{~mm}$.; head 3.14-3.32 (mean $3.19 \pm 0.02 ; \mathrm{N}=10$ ); depth 2.15-2.48 (mean $2.28 \pm 0.03 ; \mathrm{N}=10$ ).

Pulo Bakkungaan Kechil. Reef $(6 ; 48.1-54.2 \mathrm{~mm}$.) and beach (9).

\section{*Amphiprion frenatus Brevoort}

Amphiprion frenatus Brevoort, 1856, U. S. Japan Exp., 2: 263, pl. 6, fig. 4Okinawa; Schultz, 1953, Proc. U. S. Nat. Mus., 103: 200, pl. 10, fig. D.

Amphiprion ephippium de Beaufort, 1940, Fishes Indo-Austr. Arch., 8: 334 (part).

Dorsal IX,18; pectoral ii,17; ventral I,5; anal II,14; mid-lateral scales 46-49; total length 60-115 mm.; standard length 46.6-92.5 $\mathrm{mm}$.; head 3.01-3.13; depth 1.73-1.86; eye 3.36-4.67.

The juvenile is placed here with some doubt. In coloration of the ventrals and anal, it resembles ephippium Bloch, having the first rays of these otherwise pale fins black. Its dorsal counts are typical for those of frenatus (Schultz, 1953).

Pulo Bakkungaan Kechil. Reef (2).

\section{*Amphiprion percula Lacépède}

Lutjanus percula Lacépède, 1802, Hist. Nat. Poissons, 4: 194-Port Praslin, New Britain.

Amphiprion percula Cuvier in Cuvier and Valenciennes, 1830, Hist. Nat. Poissons, 5: 397; de Beaufort, 1940, Fishes Indo-Austr. Arch., 8: 345, fig. 43; Schultz, 1953, Proc. U. S. Nat. Mus., 103: 191, pl. 9, fig. C.

Dorsal XI,15; pectoral ii,15; ventral I,5; anal II,11; lateral line scales 38 ; mid-lateral scales about 47 ; total length $60 \mathrm{~mm}$.; standard length $47.1 \mathrm{~mm}$.; head 3.01; depth 2.58; eye 4.11.

Pulo Bakkungaan Kechil. Reef (1).

\section{*Cheiloprion labiatus Day}

Pomocentrus labiatus Day, 1877, Fishes India, pt. 3, p. 384, pl. 81, fig. 2Andamans and Nicobars.

Cheiloprion labiatus Weber, 1913, Fische Siboga Exp., p. 342; de Beaufort, 1940, Fishes Indo-Austr. Arch., 8: 351, fig. 45.

Dorsal XIII,11-13 (mean XIII,12.4 $\pm 0.2 ; \mathrm{N}=10$ ); pectoral ii,15-16 (mean ii,15.3 $\pm 0.2 ; \mathrm{N}=10$ ); ventral I,5; anal II,12-13 (mean $12.8 \pm 0.1 ; \mathrm{N}=10$ ); lateral line scales $16-18+6-9$; total $23-26$ (mean total $24.5 \pm 0.4 ; \mathrm{N}=10$ ); mid-lateral scales 25-27 (mean 
$25.7 \pm 0.2 ; \mathrm{N}=10$ ); total length $13-83 \mathrm{~mm}$.; standard length $10.4-$ $64.0 \mathrm{~mm}$.; head 2.61-2.86 (mean $2.76 \pm 0.03 ; \mathrm{N}=10$ ); depth $1.83-2.05$ (mean $1.92 \pm 0.02 ; \mathrm{N}=10$ ).

Pulo Bakkungaan Kechil. Reef (43).

\section{Chromis caeruleus Cuvier}

Heliases caeruleus Cuvier in Cuvier and Valenciennes, 1830, Hist. Nat. Poissons, 5: 497-New Guinea and Ulea.

Chromis caeruleus Jordan and Seale, 1906, Bull. Bur. Fish., 25: 290; de Beaufort, 1940, Fishes Indo-Austr. Arch., 8: 451, fig. 52.

Dorsal XII,9-10 (mean XII,9.6 $\pm 0.2 ; \mathrm{N}=11$ ); pectoral ii,16-18 (mean ii,17.2 $\pm 0.2 ; \mathrm{N}=11$ ); ventral I,5; anal II,9-10 (mean II, $9.4 \pm 0.2 ; \mathrm{N}=11$ ); lateral line scales $15-16+8-10$, total $23-26$ (mean total $24.7 \pm 0.2 ; \mathrm{N}=11$ ); mid-lateral scales $24-26$ (mean $24.9 \pm 0.2$; $\mathrm{N}=11$ ) ; total length $49-90 \mathrm{~mm}$.; standard length $37.3-64.6 \mathrm{~mm}$.; head 3.06-3.43 (mean 3.22 $\pm 0.03 ; \mathrm{N}=9$ ); depth 1.96-2.24 (mean $2.09 \pm 0.02 ; \mathrm{N}=10$ ).

Pulo Bakkungaan Kechil. Reef (24).

\section{Dascyllus aruanus Linnaeus}

Chaetodon aruanus Linnaeus, 1758, Syst. Nat., 10th ed., 1: 275-East Indies.

Dascyllus aruanus Cuvier in Cuvier and Valenciennes, 1830, Hist. Nat. Poissons, 5: 434; de Beaufort, 1940, Fishes Indo-Austr. Arch., 8: 467.

Dorsal XII,11-13 (mean XII,11.9 $\pm 0.2 ; \mathrm{N}=10$ ); pectoral ii,15-16 (mean ii, $15.9 \pm 0.1 ; \mathrm{N}=10$ ); ventral I,5; anal II,11-13 (mean II,12.2 $\pm 0.2 ; \mathrm{N}=10$ ); mid-lateral scales $25-26$ (mean 25.1 \pm 0.1 ; $\mathrm{N}=10$ ); total length $15.5-61 \mathrm{~mm}$.; standard length $11.5-47.3 \mathrm{~mm}$.; head 2.83-3.11 (mean 2.93 $\pm 0.03 ; \mathrm{N}=10$ ); depth 1.63-1.81 (mean $1.71 \pm 0.02 ; \mathrm{N}=10$ ).

Pulo Bakkungaan Kechil. Reef (29).

\section{Dascyllus marginatus Rüppell}

Pomacentrus marginatus Rüppell, 1828, Atlas Reise nördl. Afrika, Fische, p. 38 , pl. 38, fig. 2-Massaua, Red Sea.

Dascyllus marginatus Cuvier in Cuvier and Valenciennes, 1830, Hist. Nat. Poissons, 5: 439; de Beaufort, 1940, Fishes Indo-Austr. Arch., 8: 465, fig. 54.

Dorsal XII,14; pectoral ii,17-19; ventral I,5; anal II,13; lateral line scales $20-21+7-8$, total 27-28; mid-lateral scales $26-27$; total length 61-72.5 mm.; standard length 46.4-52.5 mm.; head 3.11-3.46; depth 1.54-1.58.

Pulo Bakkungaan Kechil. Reef (3). 


\section{Dascyllus melanurus Bleeker}

Dascyllus melanurus Bleeker, 1854, Nat. Tijd. Ned. Indië, 6: 109-Neira, Banda; de Beaufort, 1940, Fishes Indo-Austr. Arch., 8: 469.

Dorsal XII,11-13 (mean XII,11.9 $\pm 0.2 ; \mathrm{N}=10$ ) ; pectoral ii,15-16 (mean ii,15.5 $\pm 0.2 ; \mathrm{N}=10$ ); ventral I,5; anal II,11-13 (mean $\mathrm{II}, 12.1 \pm 0.2 ; \mathrm{N}=10$ ); mid-lateral scales $24-26$ (mean 25.0 \pm 0.2 ; $\mathrm{N}=10$ ); total length $10-75 \mathrm{~mm}$.; depth $1.56-1.73$ (mean $1.63 \pm 0.02$; $\mathrm{N}=10$ ).

Pulo Bakkungaan Kechil. Reef (25).

\section{Hemiglyphidodon plagiometopon Bleeker}

Glyphisodon plagiometopon Bleeker, 1853, Nat. Tijd. Ned. Indië, 3: 67Singapore.

Hemiglyphidodon plagiometopon Montalban, 1927, Monogr. Bur. Sci. Manila, no. 24 , p. 75 .

Abudefduf plagiometopon de Beaufort, 1940, Fishes Indo-Austr. Arch., 8: 428.

Dorsal XIII,12-14 (mean XIII,13.1 $\pm 0.2 ; \mathrm{N}=10$ ); pectoral ii,14-15 (mean ii,14.2 $\pm 0.1 ; \mathrm{N}=10$ ); ventral I,5; anal II,13-14 (mean II, $13.9 \pm 0.1 ; \mathrm{N}=9$ ); lateral line scales $16-20+6-9$, total $22-27$ (mean total $25.8 \pm 0.5 ; \mathrm{N}=10$ ); mid-lateral scales 25-27 (mean $26.0 \pm 0.1 ; \mathrm{N}=10$ ) ; total length 71-154 mm.; standard length 55.0 $122.5 \mathrm{~mm}$.; head $2.86-3.20$ (mean $2.98 \pm 0.04 ; \mathrm{N}=8$ ) ; depth $1.81-2.03$ (mean $1.90 \pm 0.03 ; \mathrm{N}=8$ ).

Pulo Bakkungaan Kechil. Reef (12).

\section{Pomacentrus amboinensis Bleeker}

Pomacentrus amboinensis Bleeker, 1868, Versl. Akad. Wetens. Amsterdam, (2), 2: 334-Amboina; de Beaufort, 1940, Fishes Indo-Austr. Arch., 8: 387.

Dorsal XIII,13-14 (mean XIII,13.6 $\pm 0.2 ; \mathrm{N}=7$ ); pectoral ii,15; ventral I,5; anal II,14; lateral line scales $15-17+7-8$, total $22-25$ (mean total $23.6 \pm 0.4 ; \mathrm{N}=7$ ); mid-lateral scales 25-26 (mean $25.7 \pm 0.2 ; \mathrm{N}=7$ ); total length $25-88 \mathrm{~mm}$.; standard length $19.4-68.5$ $\mathrm{mm}$.; head 3.12-3.28 (mean $3.20 \pm 0.02 ; \mathrm{N}=7$ ); depth $1.96-2.09$ (mean $2.05 \pm 0.02 ; \mathrm{N}=7$ ).

The longitudinal white lines on the anal figured by Bleeker (Atlas Ichthy., 9, pl. 406, fig. 7) and mentioned by de Beaufort are not present in this series.

Coloration of juveniles (19.4-33.6 mm.) in alcohol: dorsal part of head and back black (blue in life); a white-rimmed black ocellus 
on posterior spines and anterior rays of dorsal; sides and belly lemon yellow; interorbital stripes broader than in adults.

Pulo Bakkungaan Kechil. Reef (13).

\section{*Pomacentrus bifasciatus Bleeker}

Pomacentrus bifasciatus Bleeker, 1854, Nat. Tijd. Ned. Indië, 6: 330-Larantuka, Flores; de Beaufort, 1940, Fishes Indo-Austr. Arch., 8: 367.

Dorsal XIII,13-14; pectoral ii,15; ventral I,5; anal II,13-14; lateral line scales $17-18+8-9$; mid-lateral scales $25-27$; total length 22.5-50.5 mm.; standard length 17.1-37.6 mm.; head 2.83-2.96; depth 2.06-2.07.

The posterior black band narrows with increase in size. In the smallest specimens, the band is about twice the eye diameter. In the two largest the band equals the eye diameter.

Pulo Bakkungaan Kechil. Reef (6).

\section{*Pomacentrus chrysopoecilus Schlegel and Müller}

Pomacentrus chrysopoecilus Schlegel and Müller, 1830-41, Verh. Nat. Gesch. Ned., Zool., p. 21, pl. 5, fig. 3-Java; de Beaufort, 1940, Fishes IndoAustr. Arch., 8: 375.

Dorsal XIII,14; pectoral ii,15-16; (mean ii,15.3 $\pm 0.2 ; \mathrm{N}=10$ ); ventral I,5; anal II,13; lateral line scales 17-18+7-8, total 24-26 (mean total $24.7 \pm 0.2 ; \mathrm{N}=10$ ); mid-lateral scales 25-26 (mean $25.9 \pm 0.1 ; \mathrm{N}=10)$; total length $21-149 \mathrm{~mm}$.; standard length $15.7-$ $115.1 \mathrm{~mm}$.; head 3.07-3.31 (mean $3.21 \pm 0.02 ; \mathrm{N}=10$ ); depth 2.032.30 (mean $2.18 \pm 0.03 ; \mathrm{N}=10$ ).

Juveniles (15.7-34.9 mm.) have a light-rimmed black spot at the base of the seventh to twelfth dorsal spines. The smallest has a light vertical band from the first to fourth dorsal spines down to the pectoral and a second between the soft dorsal and soft anal. In one specimen $(24.9 \mathrm{~mm}$.), the anterior band begins at the base of the third to sixth dorsal spine; there is no posterior band.

Pulo Bakkungaan Kechil. Reef (33).

\section{*Pomacentrus chrysurus Cuvier}

Pomacentrus chrysurus Cuvier in Cuvier and Valenciennes, 1830, Hist. Nat. Poissons, 5: 423-South Seas.

Pomacentrus dorsalis Gill, 1859, Proc. Acad. Nat. Sci. Phila., 1859: 147Japan.

Pomacentrus tripunctatus de Beaufort, 1940, Fishes Indo-Austr. Arch., 8: 388 (part). 
Dorsal XIII,14-15 (mean XIII,14.8 $\pm 0.1 ; \mathrm{N}=11$ ); pectoral ii,15-16 (mean ii,15.9 $\pm 0.1 ; \mathrm{N}=11$ ); ventral I,5; anal II,14-16 (mean II,14.7 $\pm 0.2 ; \mathrm{N}=11$ ); lateral line scales $18-19+6-8$, total 24-27 (mean total 26.1 $\pm 0.3 ; \mathrm{N}=10$ ); mid-lateral scales 25-26 (mean $25.8 \pm 0.1 ; \mathrm{N}=10$ ); total length $25-64 \mathrm{~mm}$.; standard length 18.3-49.4 mm.; head 2.91-3.40 (mean 3.03 $\pm 0.02 ; \mathrm{N}=10$ ); depth 2.02-2.16 (mean $2.06 \pm 0.01 ; \mathrm{N}=11$ ).

Juveniles (18.3-34.6 mm.) have a black ocellus at the beginning of the soft dorsal.

Pulo Bakkungaan Kechil. Reef (15).

\section{Pomacentrus fasciatus Cuvier}

Pomacentrus fasciatus Cuvier in Cuvier and Valenciennes, 1830, Hist. Nat. Poissons, 5: 426-Java; de Beaufort, 1940, Fishes Indo-Austr. Arch., 8: 373 .

Dorsal XIII,13; pectoral ii,16; ventral I,5; anal II,12-13 (mean $12.7 \pm 0.2 ; \mathrm{N}=6$ ); lateral line scales $19-20+6-8$, total $26-27$ (mean total $26.5 \pm 0.2 ; \mathrm{N}=6$ ); mid-lateral scales $25-26$ (mean $25.8 \pm 0.2$; $\mathrm{N}=6$ ); total length $25.5-68 \mathrm{~mm}$.; standard length $18.2-52.0 \mathrm{~mm}$.; head 2.74-2.92; depth 1.98-2.15.

Pulo Bakkungaan Kechil. Beach (8).

\section{Pomacentrus melanopterus Bleeker}

Pomacentrus melanopterus Bleeker, 1852, Nat. Tijd. Ned. Indië, 3: $562-$ Amboina; de Beaufort, 1940, Fishes Indo-Austr. Arch., 8: 380.

Dorsal XIII,14-15 (mean XIII,14.5 $\pm 0.2 ; \mathrm{N}=12$ ); pectoral ii,14-16 (mean ii,14.9 $\pm 0.1 ; \mathrm{N}=12$ ); ventral I,5; anal II,14-15 (mean II,14.4 $\pm 0.1 ; \mathrm{N}=12$ ); lateral line scales $16-18+7-8$, total 23-26 (mean total $24.7 \pm 0.2 ; \mathrm{N}=12$ ); mid-lateral scales 25-26 (mean $25.8 \pm 0.1 ; \mathrm{N}=12$ ); total length $31.5-69.5 \mathrm{~mm}$; standard length 24.7-53.8 mm.; head 2.91-3.20 (mean $3.11 \pm 0.02 ; \mathrm{N}=12$ ); depth $1.74-2.20$ (mean $1.96 \pm 0.04 ; \mathrm{N}=12$ ).

Juveniles (24.7-26.5 mm.) have a black ocellus at the bases of the anterior soft dorsal rays.

Pulo Bakkungaan Kechil. Reef (37).

\section{*Pomacentrus moluccensis Bleeker}

Pomacentrus moluccensis Bleeker, 1853, Nat. Tijd. Ned. Indië, 4: 118Amboina and Ternate; de Beaufort, 1940, Fishes Indo-Austr. Arch., 8: 382 . 
Dorsal XIII,13-14 (mean XIII,13.7 $\pm 0.2 ; \mathrm{N}=10$ ); pectoral ii,15-16 (mean ii,15.2 $\pm 0.1 ; \mathrm{N}=10$ ); ventral I,5; anal II,13-14 (mean II, $13.7 \pm 0.2 ; \mathrm{N}=10$ ); lateral line scales $17-18+7-8$, total 24-25 (mean total 24.8 $\pm 0.1 ; \mathrm{N}=10$ ); mid-lateral scales 25-26 (mean $25.6 \pm 0.2 ; \mathrm{N}=10$ ) ; total length $22.5-60 \mathrm{~mm}$.; standard length 17.3-45.4 mm.; head 2.95-3.15 (mean 3.03 $\pm 0.02 ; \mathrm{N}=10$ ); depth $1.73-2.00$ (mean $1.92 \pm 0.03 ; \mathrm{N}=10$ ).

The spot at the beginning of the lateral line is absent in some individuals. The anal has a black edge, but no subterminal light band. The juvenile is uniformly pale yellow (in alcohol) and has no ocelli on the fins.

Pulo Bakkungaan Kechil. Reef (18).

\section{Pomacentrus notophthalmus Bleeker}

Pomacentrus notophthalmus Bleeker, 1853, Nat. Tijd. Ned. Indië, 4: 137Ternate; de Beaufort, 1940, Fishes Indo-Austr. Arch., 8: 377.

Dorsal XIII,13; pectoral ii,15-16 (mean ii,15.1 $\pm 0.1 ; \mathrm{N}=10$ ); ventral I,5; anal II,13; lateral line scales $17-18+6-8$, total 23-26 (mean total $24.6 \pm 0.3 ; \mathrm{N}=10$ ); mid-lateral scales 25-26 (mean $25.6 \pm 0.2 ; \mathrm{N}=10$ ) ; total length $35-128 \mathrm{~mm}$.; standard length 26.2 $97.3 \mathrm{~mm}$.; head $3.18-3.52$ (mean $3.29 \pm 0.03 ; \mathrm{N}=10$ ) ; depth $1.96-2.11$ (mean $2.05 \pm 0.02 ; \mathrm{N}=10$ ).

Juveniles (26.2-52.8 mm.) have a black ocellus at the base of the dorsal between the seventh to tenth spines.

Pulo Bakkungaan Kechil. Reef (22).

\section{*Pomacentrus perspicillatus Cuvier}

Pomacentrus perspicillatus Cuvier in Cuvier and Valenciennes, 1830, Hist. Nat. Poissons, 5 : 417-no locality; de Beaufort, 1940, Fishes Indo-Austr. Arch., 8: 371.

Dorsal XIII,14; pectoral ii,15-16; ventral I,5; anal II,14; lateral line scales $17-18+8-10$, total $26-27$; mid-lateral scales 27 ; total length 73-147 mm.; standard length 54.6-112 mm.; head 3.21-3.40; depth 2.08-2.38.

Pulo Bakkungaan Kechil. Reef (4).

\section{*Pomacentrus prosopotaenia Bleeker}

Pomacentrus prosopotaenia Bleeker, 1852, Nat. Tijd. Ned. Indië, 3: 67Singapore; de Beaufort, 1940, Fishes Indo-Austr. Arch., 8: 372. 
Dorsal XIII,14; pectoral ii,14-16; ventral I,5; anal II,13; lateral line scales $17+8$; mid-lateral scales 26 ; total length $87 \mathrm{~mm}$.; standard length $65.1 \mathrm{~mm}$.; head 3.21; depth 2.03.

Pulo Bakkungaan Kechil. Reef (1).

\section{Pomacentrus tripunctatus Cuvier}

Pomacentrus tripunctatus Cuvier in Cuvier and Valenciennes, 1830, Hist. Nat. Poissons, 5: 421-Vanicolo; de Beaufort, 1940, Fishes Indo-Austr. Arch., 8: 388 (part).

Dorsal XIII,13-14 (mean XIII,13.8 $\pm 0.1 ; \mathrm{N}=10$ ); pectoral ii,16-17 (mean ii,16.1 $\pm 0.1 ; \mathrm{N}=10$ ); ventral I,5; anal II,13-14 (mean II, $13.8 \pm 0.1 ; \mathrm{N}=10$ ); lateral line scales $17-19+7-9$, total 25-28 (mean total 26.5 $\pm 0.3 ; \mathrm{N}=10$ ); mid-lateral scales 25-27 (mean $25.8 \pm 0.2 ; \mathrm{N}=10$ ); total length $28-88 \mathrm{~mm}$.; standard length 19.6-67.3 mm.; head 2.95-3.30 (mean $3.13 \pm 0.03 ; \mathrm{N}=10$ ); depth $1.95-2.19$ (mean $2.07 \pm 0.03 ; \mathrm{N}=10$ ).

Pulo Bakkungaan Kechil. Reef $(30 ; 21.4-67.3 \mathrm{~mm}$.$) .$

Pulo Nunuyan Laut (37; 19.6-62.7 mm.).

\section{Premnas biaculeatus Bloch}

Chaetodon biaculeatus Bloch, 1790, Ausländ. Fische, 4: 11, pl. 219, fig. 2East Indies.

Premnas biaculeatus Bleeker, 1854, Nat. Tijd. Ned. Indië, 6: 105; de Beaufort, 1940, Fishes Indo-Austr. Arch., 8: 329, figs. 41-42.

Dorsal X,17; pectoral ii,16; ventral I,5; anal II,14; total length $23.5 \mathrm{~mm}$.; standard length $16.6 \mathrm{~mm}$.

Pulo Bakkungaan Kechil. Reef (1).

\section{PHAR YNGOGNATHI}

\section{LABRIDAE}

\section{Cheilinus chlorurus Bloch}

Sparus chlorurus Bloch, 1791, Ausländ. Fische, 5: 24, pl. 260-Japan and Santo Domingo.

Cheilinus chlorurus Bleeker, 1862, Atlas Ichthy., 1: 65, pl. 27, fig. 3; de Beaufort, 1940, Fishes Indo-Austr. Arch., 8: 76.

Dorsal X,9-10; pectoral ii,10; ventral I,5; anal III,8; lateral line scales $14-15+6-7$, total $21-22$; mid-lateral scales $17-19$; total length 30-114 mm.; standard length 23.0-90.9 mm.; head 2.48-2.53; depth 2.42-2.46.

Pulo Bakkungaan Kechil. Reef (5). 


\section{Cheilinus oxycephalus Bleeker}

Cheilinus oxycephalus Bleeker, 1853, Nat. Tijd. Ned. Indië, 5: 349-Amboina; de Beaufort, 1940, Fishes Indo-Austr. Arch., 8: 78.

Dorsal IX,10; pectoral ii,10; ventral I,5; anal III,8; lateral line scales $16+6$; mid-lateral scales 19 ; total length $98 \mathrm{~mm}$.; standard length $79.2 \mathrm{~mm}$.; head 2.44; depth 2.39 .

Pulo Bakkungaan Kechil. Reef (1).

\section{Choerodon oligacanthus Bleeker}

Crenilabrus oligacanthus Bleeker, 1851, Nat. Tijd. Ned. Indië, 2: 489-Riouw. Choirodon oligacanthus Jordan and Richardson, 1908, Bull. Bur. Fish., 27: 265. Choerodon oligacanthus de Beaufort, 1940, Fishes Indo-Austr. Arch., 8: 39.

Dorsal XIII,6-7; pectoral ii,13-14; ventral I,5; anal III,9-10; lateral line scales 26-27; total length 114-154 mm.; standard length 91.0-125 mm.; head 2.72-2.95; depth 2.78-2.96.

Pulo Nunuyan Laut (5).

\section{*Diproctacanthus xanthurus Bleeker}

Labroides xanthurus Bleeker, 1856, Acta Soc. Sci. Indo-Néerl., 1: 52-Manado, Celebes.

Diproctacanthus xanthurus Bleeker, 1861, Proc. Zool. Soc. London, 1861 : 415; de Beaufort, 1940, Fishes Indo-Austr. Arch., 8: 151, fig. 26.

Dorsal IX,10; pectoral ii,11; ventral I,5; anal II,9; lateral line scales 42 ; total length $32 \mathrm{~mm}$.; standard length $25.5 \mathrm{~mm}$.; head 2.55; depth 3.54.

Pulo Bakkungaan Kechil. Reef (1).

\section{Diproctacanthus sp.}

Dorsal IX,10; pectoral 12; anal II,8; lateral line continuous, 24 scales; total length $16 \mathrm{~mm}$.; standard length $13.2 \mathrm{~mm}$.; head 2.40 ; depth 3.67.

Color (in alcohol) dark brown; a thin median white line from tip of snout to origin of dorsal; a light stripe, approximately one scale wide, from snout through lower half of eye to end of caudal; a median ventral light band from chin to origin of anal; caudal dark brown except for longitudinal light stripe; dorsal and anal dusky.

This juvenile resembles $D$. xanthurus in having two anal spines and in details of mouth conformation. It differs from xanthurus radically in scale count (42 in xanthurus) and in coloration. The 
latter is light brown or olive with two dark bands, one from the snout through the eye to the caudal and the second from the forehead along the base of the dorsal to the top of the caudal base.

Pulo Bakkungaan Kechil. Reef (1).

\section{*Duymaeria flagellifera Valenciennes}

Ctenolabrus flagellifer Valenciennes in Cuvier and Valenciennes, 1839, Hist. Nat. Poissons, 13: 240-no locality.

Duymaeria flagellifer Bleeker, 1856, Acta Soc. Sci. Indo-Néerl., 1: 53.

Duymaeria flagellifera de Beaufort, 1940, Fishes Indo-Austr. Arch., 8: 140, fig. 23.

Dorsal IX,12; pectoral ii,11; ventral I,5; anal III,9; lateral line scales 23; total length $57 \mathrm{~mm}$.; standard length $45.2 \mathrm{~mm}$.; head 2.60 ; depth 2.44 .

Pulo Bakkungaan Kechil. Reef (1).

\section{*Halichoeres amboinensis Bleeker}

Julis (Halichoeres) amboinensis Bleeker, 1856, Acta Soc. Sci. Indo-Néerl., 1: 55-Amboina.

Halichoeres amboinensis de Beaufort, 1940, Fishes Indo-Austr. Arch., 8: 223.

Dorsal IX,12; pectoral ii,12; ventral I,5; anal III,12; lateral line scales 27; total length $120 \mathrm{~mm}$.; standard length $101.7 \mathrm{~mm}$.; head 3.07; depth 2.91.

Pulo Nunuyan Laut (1).

\section{Halichoeres argus Bloch and Schneider}

Labrus argus Bloch and Schneider, 1801, Syst. Ichthy., p. 263-Australia.

Halichoeres argus Jordan and Seale, 1907, Bull. Bur. Fish., 26: 30; de Beaufort, 1940, Fishes Indo-Austr. Arch., 8: 230, fig. 34A.

Dorsal IX,12; pectoral ii,11-12 (mean ii,11.8 $\pm 0.2 ; \mathrm{N}=6$ ); ventral I,5; anal III,11-12 (mean III,11.7 $\pm 0.2 ; \mathrm{N}=6$ ); lateral line scales 24-27 (mean 25.8 $\pm 0.5 ; \mathrm{N}=6$ ); total length $54.5-67.5 \mathrm{~mm}$.; standard length 45.2-55.7 mm.; head 2.72-2.92; depth 3.16-3.62.

Pulo Bakkungaan Kechil. Beach (6).

\section{Halichoeres bicolor Bloch and Schneider}

Labrus bicolor Bloch and Schneider, 1801, Syst. Ichthy., p. 267-no locality. Halichoeres bicolor Bleeker, 1862, Atlas Ichthy., 1: 118, pl. 39, fig. 5; de Beaufort, 1940, Fishes Indo-Austr. Arch., 8: 205. 
Dorsal IX,12; pectoral ii,12; ventral I,5; anal III,12; lateral line scales 28; total length $87 \mathrm{~mm}$.; standard length $73.0 \mathrm{~mm}$.; head 2.99; depth 3.46 .

Pulo Nunuyan Laut (1).

\section{*Halichoeres gymnocephalus Bloch and Schneider}

Labrus gymnocephalus Bloch and Schneider, 1801, Syst. Ichthy., p. 251no locality.

Halichoeres gymnocephalus Jordan and Richardson, 1908, Bull. Bur. Fish., 27 : 266; de Beaufort, 1940, Fishes Indo-Austr. Arch., 8: 234.

Dorsal IX,11; pectoral ii,12; ventral I,5; anal III,11; lateral line scales 27-28; total length 29-102 mm.; standard length 24.4-83.6 $\mathrm{mm}$.; head 2.76-2.91; depth 2.84-3.28.

Juveniles (24.4-35.5 mm.) lack the dark lateral blotch.

Pulo Bakkungaan Kechil. Reef (7).

\section{Halichoeres hyrtli Bleeker}

Julis (Halichoeres) hyrtlii Bleeker, 1856, Acta Soc. Sci. Indo-Néerl., 1: 60Makassar.

Halichoeres hyrtli de Beaufort, 1940, Fishes Indo-Austr. Arch., 8: 220.

Dorsal IX,12; pectoral ii,11-12; ventral I,5; anal III,11-12; lateral line scales 27 ; total length $36-69 \mathrm{~mm}$; standard length 28.7-56.9 mm.; head 2.81-2.98; depth 3.47-3.60.

Pulo Nunuyan Laut (3).

\section{*Halichoeres leparensis Bleeker}

Julis (Halichoeres) leparensis Bleeker, 1852, Nat. Tijd. Ned. Indië, 3: 730Lepar.

Halichoeres leparensis de Beaufort, 1940, Fishes Indo-Austr. Arch., 8: 211, fig. $34 c$.

Dorsal IX,12; pectoral ii,12; ventral I,5; anal III,11-12 (mean III,11.7 $\pm 0.1 ; \mathrm{N}=15$ ); lateral line scales $26-27$ (mean $26.8 \pm 0.1$; $\mathrm{N}=15$ ); total length 23.5-64 mm.; standard length $19.1-52.0 \mathrm{~mm}$.; head 2.74-2.96 (mean 2.81 $\pm 0.02 ; \mathrm{N}=10$ ); depth 3.55-3.91 (mean $3.72 \pm 0.03 ; \mathrm{N}=10$ ).

Pulo Bakkungaan Kechil. Reef $(8 ; 25.6-49.8 \mathrm{~mm}$.) and beach (40; 21.5-49.0 mm.).

Pulo Nunuyan Laut (4; 19.1-52.0 mm.). 
*Halichoeres nigrescens Bloch and Schneider

Labrus nigrescens Bloch and Schneider, 1801, Syst. Ichthy., p. 263-no locality.

Halichoeres nigrescens Bleeker, 1862, Atlas Ichthy., 1: 118, pl. 37, fig. 4; de Beaufort, 1940, Fishes Indo-Austr. Arch., 8: 207.

Dorsal IX,12; pectoral ii,12-14 (mean ii,13.0 $\pm 0.1 ; \mathrm{N}=13$ ); ventral I,5; anal III,11-12 (mean III,11.8 $\pm 0.1 ; \mathrm{N}=13$ ); lateral line scales 26-27 (mean $26.8 \pm 0.1 ; \mathrm{N}=13$ ); total length $35.5-100 \mathrm{~mm}$.; standard length 28.8-83.0 mm.; head 2.79-3.02 (mean 2.92 \pm 0.02 ; $\mathrm{N}=10$ ); depth $3.05-3.39$ (mean $3.20 \pm 0.04 ; \mathrm{N}=10$ ).

The black ocellus on the spinous dorsal is not always present. Juveniles (28.8-ca. $40 \mathrm{~mm}$.) have a black spot between the third and sixth soft dorsal rays.

Pulo Nunuyan Laut (104).

\section{Halichoeres scapularis Bennett}

Julis scapularis Bennett, 1831, Proc. Zool. Soc. London, 1831: 167-Mauritius.

Halichoeres scapularis Jordan and Seale, 1907, Bull. Bur. Fish., 26: 29; de Beaufort, 1940, Fishes Indo-Austr. Arch., 8: 186.

Dorsal IX,11; pectoral ii,12; ventral I,5; anal III,11; lateral line scales 25-26; total length 33.5-49.0 mm.; standard length 27.3-40.2 mm.; head 2.70-2.85; depth 3.59-4.00.

Pulo Bakkungaan Kechil. Reef $(6 ; 27.3-30.6 \mathrm{~mm}$.) and beach (3; 30.8-40.2 mm.).

\section{*Labroides dimidiatus Valenciennes}

Cossyphus dimidiatus Valenciennes in Cuvier and Valenciennes, 1839, Hist. Nat. Poissons, 13: 136-Tor, Red Sea.

Labroides dimidiatus Günther, 1862, Cat. Fishes Brit. Mus., 4: 119; de Beaufort, 1940, Fishes Indo-Austr. Arch., 8: 148, fig. 25.

Dorsal IX,11; pectoral ii,11; ventral I,5; anal III,10; lateral line scales 48 ; total length $47 \mathrm{~mm}$.; standard length $38.2 \mathrm{~mm}$.; head 2.96; depth 4.24.

This specimen has the entire preopercle, opercle, and cheek scaled, contrary to de Beaufort $(1940$, p. 149), who states that the head is naked except for the upper portions of the preopercle and opercle.

Pulo Bakkungaan Kechil. Reef (1).

\section{*Stethojulis kalosoma Bleeker}

Julis (Halichoeres) kalosoma Bleeker, 1852, Nat. Tijd. Ned. Indië, 3: 289Amboina and Wahai, Ceram. 
Stethojulis kalosoma Bleeker, 1862, Atlas Ichthy., 1: 134, pl. 43, fig. 4; de Beaufort, 1940, Fishes Indo-Austr. Arch., 8: 165.

Dorsal IX,11; pectoral ii,11; ventral I,5; anal III,11; lateral line scales 25; total length $58 \mathrm{~mm}$.; standard length $46.9 \mathrm{~mm}$.; head 2.72; depth 3.88.

\section{Pulo Bakkungaan Kechil. Beach (1).}

\section{*Stethojulis phekadopleura Bleeker}

Julis (Halichoeres) phekadopleura Bleeker, 1849, Verh. Bat. Gen., 22: 8-Bali. Stethojulis phekadopleura Bleeker, 1862, Atlas Ichthy., 1: 134, pl. 43, fig. 5; de Beaufort, 1940, Fishes Indo-Austr. Arch., 8: 164.

Dorsal IX,11; pectoral ii,10-13 (mean ii,11.1 $\pm 0.2 ; \mathrm{N}=12$ ); ventral I,5; anal III,10-11 (mean III,10.9 $\pm 0.1 ; \mathrm{N}=12$ ); lateral line scales 24-27 (mean $25.6 \pm 0.2 ; \mathrm{N}=15$ ); total length $23-101 \mathrm{~mm}$; standard length 18.0-84.8 mm.; head 2.60-2.90 (mean 2.75 \pm 0.03 ; $\mathrm{N}=8$ ); depth 2.90-4.19.

Depth varies with age. The figures given by de Beaufort for this character (3-3.3) apply only to larger specimens, as the following tabulation shows (standard length in parentheses): 4.10 (34.4), 4.19 (38.1), 3.90 (39.0), 3.98 (43.4), 3.38 (47.3), 3.82 (48.5), 3.15 (51.4), 3.16 (67.0), 2.96 (82.5), 2.90 (84.8).

Pulo Bakkungaan Kechil. Reef $(8 ; 18.0-84.8 \mathrm{~mm}$.) and beach $(10 ; 34.3-67.0 \mathrm{~mm}$.).

\section{Stethojulis strigiventer Bennett}

Julis strigiventer Bennett, 1832, Proc. Zool. Soc. London, 1832: 184-Mauritius.

Stethojulis strigiventer Günther, 1861, Ann. Mag. Nat. Hist., (3), 8: 386; de Beaufort, 1940, Fishes Indo-Austr. Arch., 8: 163.

Dorsal IX,10-11 (mean IX,10.9 $\pm 0.1 ; \mathrm{N}=9$ ); pectoral ii,12-13 (mean ii,12.9 $\pm 0.1 ; \mathrm{N}=9$ ); ventral I,5; anal III,11; lateral line scales 25-26 (mean $25.6 \pm 0.2 ; \mathrm{N}=9$ ); total length $34-98 \mathrm{~mm}$.; standard length 27.8-81.5 mm.; head 2.48-2.91 (mean 2.71 \pm 0.04 ; $\mathrm{N}=10$ ); depth $3.21-3.51$ (mean $3.38 \pm 0.03 ; \mathrm{N}=10$ ).

Pulo Bakkungaan Kechil. Reef (11).

\section{*Stethojulis trilineata Bloch and Schneider}

Labrus trilineatus Bloch and Schneider, 1801, Syst. Ichthy., p. 253-Coromandel.

Stethojulis trilineata Günther, 1861, Ann. Mag. Nat. Hist., (3), 8: 386; de Beaufort, 1940, Fishes Indo-Austr. Arch., 8: 156. 
Dorsal IX,11; pectoral ii,11; ventral I,5; anal III,11; lateral line scales 25; total length $121 \mathrm{~mm}$.; standard length $100 \mathrm{~mm}$.; head 2.72; depth 2.79 .

Pulo Bakkungaan Kechil. Reef (1).

\section{*Thalassoma hardwicki Bennett}

Sparus hardwickii Bennett, 1828-30, Select. Fishes Ceylon, pl. 12-Ceylon.

Thalassoma hardwicke Fowler, 1925, Bull. Bishop Mus., no. 22, p. 35.

Thalassoma hardwicki de Beaufort, 1940, Fishes Indo-Austr. Arch., 8: 112; fig. 22.

Dorsal VIII,13; pectoral ii,14; ventral I,5; anal III,10-11; lateral line scales 25-26; total length 105-155 mm.; standard length 84.0-124 mm.; head 2.85-2.92; depth 2.90-3.13.

Pulo Bakkungaan Kechil. Reef (4).

\section{Thalassoma lunare Linnaeus}

Labrus lunaris Linnaeus, 1758, Syst. Nat., 10th ed., 1: 283-East Indies.

Thalassoma lunare Fowler, 1904, Jour. Acad. Nat. Sci. Phila., (2), 12: 537, pl. 3; de Beaufort, 1940, Fishes Indo-Austr. Arch., 8: 133.

Dorsal VIII,13; pectoral ii,13; ventral I,5; anal III,11; lateral line scales 25-26; total length 67-95 mm.; standard length 55.0-77.6 $\mathrm{mm}$; ; head 3.21; depth 3.15 .

Pulo Bakkungaan Kechil. Reef (2).

\section{SCARIDAE}

Callyodon blochi Valenciennes

Scarus blochii Valenciennes in Cuvier and Valenciennes, 1839, Hist. Nat. Poissons, 14: 219-Java.

Callyodon blochi Jordan and Seale, 1906, Bull. Bur. Fish., 25: 326; de Beaufort, 1940, Fishes Indo-Austr. Arch., 8: 309.

Dorsal IX,10; pectoral ii,12; ventral I,5; anal III,9; lateral line scales 22-23; total length 168-196.5 mm.; standard length 143-155 mm.; head 2.83-2.99; depth 2.41-2.61.

Pulo Bakkungaan Kechil. Reef (2).

\section{Callyodon sp.}

Dorsal IX,9-10; pectoral ii,12; ventral I,5; anal III,9; lateral line scales 21-24; total length 117.5-162 mm.; standard length 96.3-135 mm.; head 2.80-2.97; depth 2.47-2.76.

Pulo Bakkungaan Kechil. Reef (9). 
Leptoscarus vaigiensis Quoy and Gaimard

Scarus vaigiensis Quoy and Gaimard, 1824, Voy. Uranie, Zool., p. 288Waigeu.

Leptoscarus vaigiensis Fowler, 1927, Bull. Bishop Mus., no. 38, p. 25; de Beaufort, 1940, Fishes Indo-Austr. Arch., 8: 257, fig. 38.

Dorsal IX,9-10; pectoral ii,11; ventral I,5; anal III,9; lateral line scales 23 ; total length $68.5-109 \mathrm{~mm}$.; standard length $53.5-87.8$ mm.; head 2.70-2.95; depth 2.80-3.02.

Pulo Nunuyan Laut (2).

\section{GOBIOIDEA \\ GOBIIDAE}

\section{*Acentrogobius ornatus Rüppell}

Gobius ornatus Rüppell, 1828, Atlas Reise nördl. Afrika, Fische, p. 135Massaua, Red Sea.

Acentrogobius ornatus Koumans, 1935, Zool. Meded. Leiden, 18: 137.

Dorsal VI-I,9-11 (mean I,9.8 $\pm 0.2 ; \mathrm{N}=9$ ); pectoral ii,15-17 (mean ii,15.6 $\pm 0.3 ; \mathrm{N}=8$ ); ventral I,5; anal I,9; mid-lateral scales 26-28 (mean 26.3 $\pm 0.3 ; \mathrm{N}=6$ ); predorsals 6-9 (mean 7.6 \pm 0.4 ; $\mathrm{N}=7$ ); total length $26-59 \mathrm{~mm}$.; standard length $20.0-46.0 \mathrm{~mm}$.; head 3.33-3.62 (mean $3.49 \pm 0.04 ; \mathrm{N}=7$ ); depth 5.11-6.00.

Pulo Bakkungaan Kechil. Reef $(9 ; 21.5-35.0 \mathrm{~mm}$.) and beach (2; 31.4-35.0 mm.).

Pulo Nunuyan Laut (7; 20.0-46.0 mm.).

\section{*Acentrogobius reichei Bleeker}

Gobius reichei Bleeker, 1853, Nat. Tijd. Ned. Indië, 5: 509-Padang, Sumatra. Acentrogobius reichei Koumans, 1941, Mem. Indian Mus., 13: 232.

Dorsal VI-I,9-10; pectoral 15-16; ventral I,5; anal I,8-9; mid-lateral scales $28-30$; predorsals $9-10$; total length $21.5-31 \mathrm{~mm}$.; standard length 16.6-24.4 mm.; head 2.84-2.98; depth 4.78 .

Pulo Nunuyan Laut (4).

\section{Amblygobius linki Herre}

Amblygobius linki Herre, 1927, Monogr. Bur. Sci. Manila, no. 23, p. 231, pl. 18, fig. 4-Bungau, Sulu Islands.

Dorsal VI-I,12-13; pectoral 18; ventral I,5; anal I,12-13; mid-lateral scales 53-59; total length 56.5-72 mm.; standard length 43.2-55.3 mm.; head 3.43-3.95. 


\section{Pulo Nunuyan Laut (1).}

Sandakan Fish Market (3).

\section{*Amblygobius phalaena Valenciennes}

Gobius phalaena Valenciennes in Cuvier and Valenciennes, 1837, Hist. Nat. Poissons, 12: $92-$ Vanicolo.

Amblygobius phalaena Jordan and Seale, 1906, Bull. Bur. Fish., 25: 405.

Dorsal VI-I,14; pectoral 17-19 (mean 18.2 $\pm 0.3 ; \mathrm{N}=6$ ); ventral $\mathrm{I}, 5$; anal $\mathrm{I}, 13-14$ (mean I,13.7 $\pm 0.2 ; \mathrm{N}=6$ ); mid-lateral scales 50-55 (mean $52.1 \pm 0.7 ; \mathrm{N}=7$ ); total length $25-57 \mathrm{~mm}$.; standard length 18.8-44.2 mm.; head 3.00-3.25 (mean $3.11 \pm 0.03$; $\mathrm{N}=8$ ) ; depth 3.48 4.31 (mean $3.82 \pm 0.09 ; \mathrm{N}=8$ ).

Pulo Bakkungaan Kechil. Reef $(22 ; 18.8-44.2 \mathrm{~mm}$.) and beach (2; 31.3-39.0 mm.).

\section{*Bathygobius fuscus Rüppell}

Gobius fuscus Rüppell, 1828, Atlas Reise nördl. Afrika, Fische, p. 137Red Sea.

Bathygobius fuscus Jordan and Jordan, 1922, Mem. Carnegie Mus., 10: 78.

Dorsal VI-I,8-9; pectoral 19, 5-6 free rays; ventral I,5; anal I,7; mid-lateral scales 36-39; predorsals 15; standard length 31.4$38.8 \mathrm{~mm}$.; head 2.98-3.14; depth 4.56.

Pulo Bakkungaan Kechil. Beach (2).

\section{Callogobius hasselti Bleeker}

Eleotris hasseltii Bleeker, 1851, Nat. Tijd. Ned. Indië, 1: 253-Anjea, Java. Callogobius hasseltii Bleeker, 1874, Arch. Néerl. Sci. Ex. Nat., 9: 318.

Dorsal VI-I,9; pectoral 16; ventral I,5; anal I,8; total length $32 \mathrm{~mm}$.; standard length $24.0 \mathrm{~mm}$; head 3.24; depth 6.15 .

Pulo Bakkungaan Kechil. Reef (1).

*Glossogobius sandakanensis, new species. Figure 6.

Type.-Chicago Natural History Museum no. 59526. A male from brackish water in the Mankala River, Mile 2, North Road, Sandakan, North Borneo.

Description of type.-Dorsal profile convex, rising in a straight line from snout tip to origin of first dorsal; ventral profile sloping downward for length of lower jaw, thence sub-horizontal; head depressed, body compressed; anterior nostril with short tube, separated from larger posterior nostril by diameter of latter; poste- 
rior nostril roughly mid-way between orbit and upper jaw; eye moderate (4.94 in head), about four-fifths of snout; the latter 3.49 in head; interorbital 2.40 in eye diameter; maxilla extending below iris; lower jaw slightly projecting; conical, pointed teeth in pluriserial bands in both jaws, the outer and inner rows in lower jaw with longer teeth; tongue bilobate.

Two longitudinal rows of papillae forward from each eye ending opposite posterior nostril; three transverse rows on tip of snout opposite nostrils, none reaching mid-line, the first longest, the last shortest; five longitudinal rows over cheek and preopercle, all crisscrossed by many short transverse rows beginning at the orbit and high on the preopercle; opercle with a vertical row anteriorly and two curved longitudinal rows, the three forming a stirrup; all rows of papillae single. One mucous pore antero-mesad from each posterior nostril; a pore opposite center and one opposite end of eye in mid-line of interorbital; a large pore behind eye, two close together in dorsal border of preopercle, one in dorsal border of opercle, and three in a vertical series between preopercle and opercle.

Scales large, ctenoid, beginning behind eyes on top of head; opercle with three longitudinal series of scales dorsally; head otherwise naked; mid-lateral series 31 ; predorsals 17 ; transverse series between origins of second dorsal and anal 9 .

First dorsal spinous, origin three scales behind base of pectoral; one scale between dorsals; origin of second dorsal opposite genital papilla; first dorsal spine subequal to postorbital part of head; second spine elongated, reaching third branched ray of second dorsal; rays of second dorsal subequal to each other and spines of first dorsal; tips of dorsal rays separated from caudal by three scales; base of pectoral fleshy, tips of longest (middle) rays reaching beneath second ray of soft dorsal; ventrals united, inserted below pectoral base, interspinous membrane well developed, reaching ends of spines; tips of longest ventral rays reaching vent; origin of anal slightly behind that of second dorsal; anal base equal to postorbital part of head and shorter than soft dorsal base; anal rays increasing in length posteriorly; caudal obtusely pointed, asymmetrical, the upper half longer.

Color (in alcohol) brown, lighter below; an oblique black bar from beneath posterior nostril to lower corner of orbit; a black square on opercle anteriorly; a mid-lateral series of five squarish black spots, the first below anterior spines of first dorsal, the second below anterior rays of soft dorsal, the third opposite end of second 
dorsal, the fourth in center of caudal peduncle, and the fifth at base of caudal; several series of small dark dots above and below spots; ventral surface unmarked; spines and rays of both dorsals marked
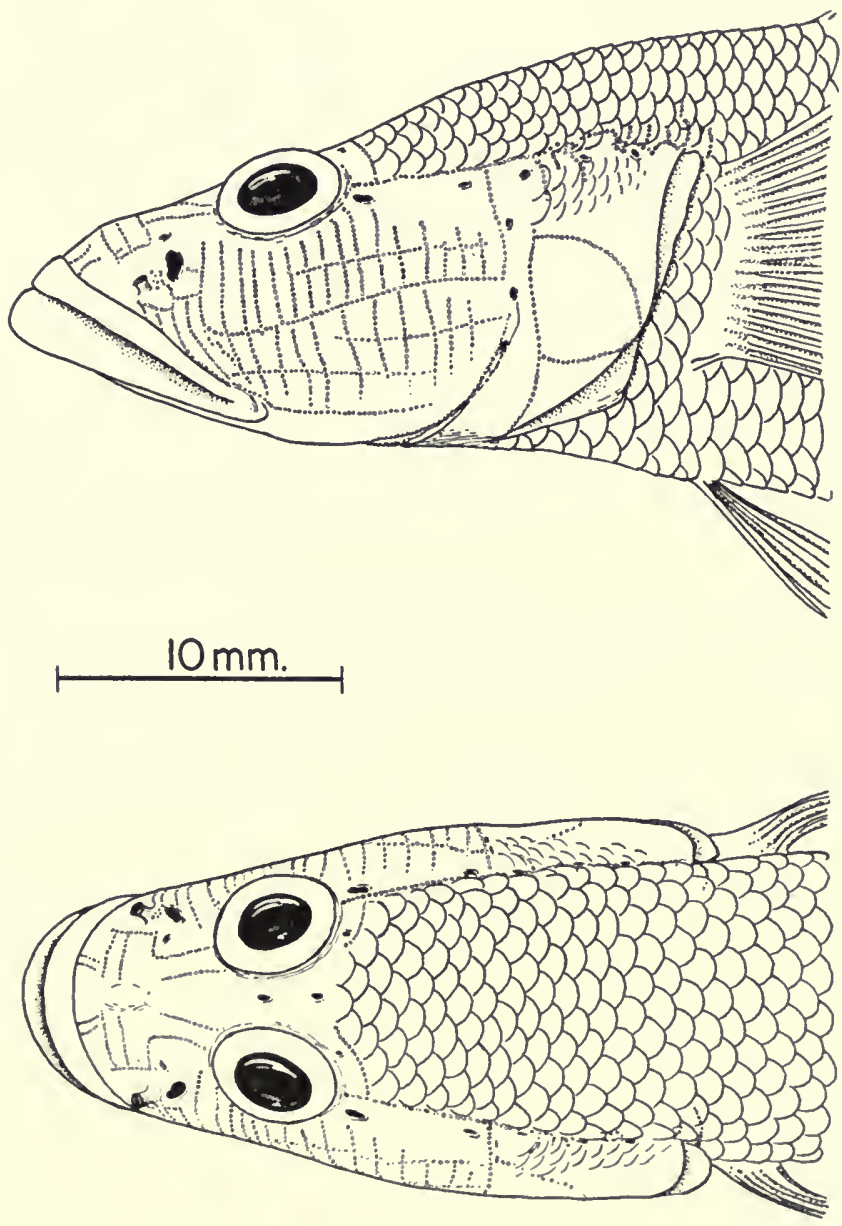

FIG. 6. Lateral and dorsal views of head of Glossogobius sandakanensis, new species.

with black checks, membranes dusky; middle of pectoral base with dark spot, rays dusky, membrane clear; rays and membrane of ventral and anal fins dusted with fine chromatophores; caudal rays checked with black, membrane dusky. 
Dorsal VI-I,8; pectoral 19; ventral I,5; anal I,8; mid-lateral scales 31 ; total length $96 \mathrm{~mm}$.; standard length $75.3 \mathrm{~mm}$.; head 2.87 (26.2 mm.); depth 4.70 at origin of spinous dorsal (16.0 mm.).

Comparison with other species.-The numerous transverse rows of papillae on the cheek and preopercle separate sandakanensis from all other Glossogobius except biocellatus Valenciennes. In the latter, however, the transverse rows do not extend onto the upper half of the preopercle and therefore cover only half the area occupied in sandakanensis. The presence of the projection of the iris and the absence of either transverse or longitudinal rows of papillae on the top of the snout in biocellatus further distinguish it from sandakanensis. Glossogobius brunneus Temminck and Schlegel (range, Japan) has transverse rows of papillae on the side of the head, but these are limited to the pre- and suborbital areas. Glossogobius brunneus also differs from sandakanensis in predorsal scalation (over 25 scales in brunneus) and in other features of papillae distribution (see below).

Glossogobius sandakanensis has three transverse rows of papillae on the top of the snout. These rows are straight and do not reach the mid-line. A curved transverse row completely crosses the snout in giurus Hamilton and celebius Valenciennes. Neither matanensis Weber nor intermedius Aurich has transverse rows in this area.

The following key will serve to identify the Indo-Australian species of Glossogobius:

1a. A projection from upper part of iris into pupil; predorsals less than 20 .

biocellatus Valenciennes

1b. No projection from iris . . . . . . . . . . . . . . . . . . . . .

2a. No transverse rows of papillae on cheek or preopercle $\ldots \ldots \ldots \ldots \ldots \ldots$

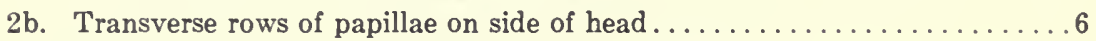

3a. Predorsals 21 or less, usually less than $20 \ldots \ldots \ldots \ldots \ldots \ldots \ldots$

3b. Predorsals 21 or more, usually 24 or more . . . . . . . . . . . . .

4a. No transverse internasal row of papillae; papillae of cheek in double or triple rows; scales on opercle in $4-5$ rows............ intermedius Aurich

4b. A transverse internasal row of papillae; papillae of cheek in single rows; scales of opercle in $2-3$ rows...................elebius Valenciennes

5a. No transverse internasal row of papillae; rows of papillae on cheek pluri-

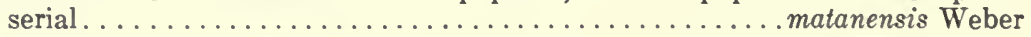

5b. A transverse internasal row of papillae; rows of papillae on cheek single.

giurus Hamilton

6a. Predorsals 25 or more; no transverse rows of papillae on top of snout; no transverse rows on preopercle..........brunneus Temminck and Schlegel

6b. Predorsals less than 20; three short transverse rows of papillae on top of snout; transverse rows of papillae on preopercle..... sandakanensis, new sp. 
*Gobiodon citrinus Rüppell

Gobius citrinus Rüppell, 1825, Neue Wirbelth., Fische, p.139, pl. 32, fig. 4Massaua, Red Sea.

Gobiodon citrinus Günther, 1861, Cat. Fishes Brit. Mus., 3: 87.

Dorsal VI-I,10; pectoral 19-20; ventral I,5; anal I,8-9; total length 27.5-43.5 mm.; standard length $22.2-33.8 \mathrm{~mm}$.; head 2.963.02 ; depth 2.54-2.71.

Pulo Bakkungaan Kechil. Reef (2).

\section{*Gobiodon erythrospilus Bleeker}

Gobiodon erythrospilus Bleeker, 1875, Arch. Néerl. Sci. Ex. Nat., 10: 122Solor.

Dorsal VI-I,9-10; pectoral 18-19; ventral I,5; anal I,8-9; total length 18-39 mm.; standard length $14.4-32.0 \mathrm{~mm}$.; head 3.133.33; depth 2.23-2.41.

Pulo Bakkungaan Kechil. Reef (6).

\section{Paragobiodon echinocephalus Rüppell}

Gobius echinocephalus Rüppell, 1828, Atlas Reise nördl. Afrika, Fische, p. 136, pl. 34, fig. 3-Massaua, Red Sea.

Paragobiodon echinocephalus Bleeker, 1873, Ned. Tijd. Dierk., 4: 129.

Dorsal VI-I,9; pectoral 21; ventral I,5; anal I,8; mid-lateral scales 23; total length $23 \mathrm{~mm}$.; standard length $18.5 \mathrm{~mm}$.; head 2.98; depth 3.19.

Pulo Bakkungaan Kechil. Reef (1).

\section{*Pseudogobius javanicus Bleeker}

Gobius javanicus Bleeker, 1856, Nat. Tijd. Ned. Indië, 11: 88-Java.

Pseudogobius javanicus Aurich, 1938, Int. Rev. Ges. Hydrobiol., 28: 158.

Dorsal VI-I,7; pectoral 13; ventral I,5; anal I,8; mid-lateral scales 25; predorsals 7 ; total length $22.5 \mathrm{~mm}$.; standard length 18.3 mm.; head 3.59; depth 3.98; eye 3.16.

Mankala River in brackish water (1).

\section{ELEOTRIDAE}

*Eviota distigma Jordan and Seale

Eviota distigma Jordan and Seale, 1906, Bull. Bur. Fish., 25: 389, fig. 79Samoa. 
Dorsal VI-I,8; pectoral 17; ventral I,5; anal 9; mid-lateral scales 24 ; total length $20 \mathrm{~mm}$.; standard length $16.2 \mathrm{~mm}$.; head 3.38; depth 4.37.

Pulo Bakkungaan Kechil. Reef (1).

\section{Valenciennea longipinnis Lay and Bennett}

Eleotris longipinnis Lay and Bennett, 1839, Zool. Capt. Beechey's Voy., p. 64 , pl. 20, fig. 3-Riukiu Islands.

Valenciennea longipinnis Jordan and Seale, 1906, Bull. Bur. Fish., 25: 382.

Dorsal VI-I,12; pectoral 20; ventral I,5; anal I,12; mid-lateral scales 110; total length $130 \mathrm{~mm}$.; standard length $95.5 \mathrm{~mm}$.; head 3.34; depth 5.03 .

Pulo Bakkungaan Kechil. Reef (1).

\section{Valenciennea muralis Valenciennes}

Eleotris muralis Valenciennes in Cuvier and Valenciennes, 1837, Hist. Nat. Poissons, 12: 190, pl. 357-Tukopia, Taiboa Islands.

Valenciennea muralis Jordan and Snyder, 1901, Proc. U. S. Nat. Mus., 24: 42 (part).

Dorsal VI-I,12; pectoral 20; ventral I,5; anal I,11-12 (mean I,11.9 $\pm 0.1 ; \mathrm{N}=7$ ); mid-lateral scales about 90 ; total length 28.5 $76.5 \mathrm{~mm}$.; standard length $22.0-56.0 \mathrm{~mm}$. ; head $2.93-3.10$.

Pulo Bakkungaan Kechil. Reef (15; 22.0-46.2 mm.) and beach (11; 37.8-55.9 mm.).

Pulo Nunuyan Laut $(4 ; 24.9-56.0 \mathrm{~mm}$.).

\section{JUGULARES \\ OPISTHOGNATHIDAE}

\section{*Opisthognathus rosenbergi Bleeker}

Opisthognathus rosenbergi Bleeker, 1856, Nat. Tijd. Ned. Indië, 12: 220Nias; de Beaufort, 1951, Fishes Indo-Austr. Arch., 9: 38.

Dorsal X-XI,13-14; pectoral i,19; ventral I,5; anal II,12-13; lateral line pores 60-70; mid-lateral scales 70-77; total length 26-148 mm.; standard length 19.5-117 mm.; head 2.49-2.69; depth $3.23-3.84$.

Pulo Nunuyan Laut (3). 


\section{CALLIONYMIDAE}

\section{*Synchiropus ocellatus Pallas}

Callionymus ocellatus Pallas, 1770, Spicil. Zool., 8: 26, pl. 4, figs. 1-3-Amboina.

Synchiropus ocellatus Gill, 1860, Proc. Acad. Nat. Sci. Phila., 1859: 130; de Beaufort, 1951, Fishes Indo-Austr. Arch., 9: 71, fig. 14.

Dorsal IV-i,7; pectoral 20; anal i,6; ventral I,5; total length $29.5 \mathrm{~mm}$.; standard length $22.5 \mathrm{~mm}$.; head 2.62; depth 5.62 .

Schultz and Woods (1948) state that all anal rays but the last are unbranched. The present specimen has all but the first anal ray branched. De Beaufort's figure also shows branched anal rays.

Pulo Bakkungaan Kechil. Beach (1).

\section{BLENNIIDAE}

\section{*Atrosalarias fuscus Rüppell}

Salarias fuscus Rüppell, 1836, Neue Wirbelth., Fische, p. 135, pl. 32, fig. $2-$ Massaua, Red Sea.

Atrosalarias fuscus Chapman in de Beaufort, 1951, Fishes Indo-Austr. Arch., 9: 255 , fig. 44 .

Dorsal XI,19; pectoral 16; ventral I,2; anal II,19; total length 25-42 mm.; standard length 19.0-31.4 mm.; head 3.30; depth 3.01.

Pulo Bakkungaan Kechil. Reef (2).

\section{*Petroscirtes rhynorhynchus Bleeker}

Petroskirtes rhynorhynchus Bleeker, 1852, Nat. Tijd. Ned. Indië, 3: 273Wahai, Ceram.

Petroscirtes rhynorhynchus de Beaufort, 1951, Fishes Indo-Austr. Arch., 9: 361 .

Dorsal 43; pectoral 12; ventral 2; anal 31; total length $67 \mathrm{~mm}$.; standard length $56.6 \mathrm{~mm}$.; head 5.01; depth 7.08.

This specimen has four short subequal barbels (approximately equal to the diameter of the pupil) on the chin immediately behind the lower jaw. These structures have not been noted in previous descriptions.

Pulo Bakkungaan Kechil. Reef (1).

\section{*Salarias cyanostigma Bleeker}

Salarias cyanostigma Bleeker, 1849, Verh. Bat. Gen., 22: 5-East Indies; Chapman in de Beaufort, 1951, Fishes Indo-Austr. Arch., 9: 332. 
Dorsal XIII,19-21 (one with 14 spines; mean XIII,19.7 \pm 0.2 ; $\mathrm{N}=9$ ) ; pectoral 14 ; ventral I,3; anal II,20-22 (mean II,20.9 \pm 0.2 ; $\mathrm{N}=9$ ) ; total length $43-67.5 \mathrm{~mm}$; ; standard length $36.0-56.0 \mathrm{~mm}$.; head 4.09-4.59 (mean $4.30 \pm 0.06 ; \mathrm{N}=7$ ); depth 4.71-5.84 (mean $5.20 \pm 0.14 ; \mathrm{N}=7$ ).

Pulo Bakkungaan Kechil. Beach (9).

\section{*Salarias fasciatus Bloch}

Blennius fasciatus Bloch, 1786, Ausländ. Fische, 2: 110, pl. 162, fig. 1-East Indies.

Salarias fasciatus Valenciennes in Cuvier and Valenciennes, 1836, Hist. Nat. Poissons, 11: 324; Chapman in de Beaufort, 1951, Fishes Indo-Austr. Arch., 9: 315 .

Dorsal XII-XIII,18-19; pectoral 14-15; ventral I,2; anal II,19-20; total length $58-137 \mathrm{~mm}$.; standard length $45.5-110 \mathrm{~mm}$.; head 3.90-4.31; depth 3.03-3.57.

Pulo Bakkungaan Kechil. Reef $(2 ; 107-110 \mathrm{~mm}$.) and beach (4; 45.5-52.8 mm.).

\section{*Salarias guttatus Valenciennes}

Salarias guttatus Valenciennes in Cuvier and Valenciennes, 1836, Hist. Nat. Poissons, 11: 308-Vanikoro; Chapman in de Beaufort, 1951, Fishes Indo-Austr. Arch., 9: 320.

Dorsal XII,16-18 (one with 13 spines; mean XII,17.0 \pm 0.2 ; $\mathrm{N}=13$ ); pectoral 14; ventral I,2; anal II,18-20 (mean II,18.5 \pm 0.2 ; $\mathrm{N}=13$ ); total length $21.5-50 \mathrm{~mm}$; standard length $17.2-40.6 \mathrm{~mm}$.; head $3.98-4.38$ (mean $4.14 \pm 0.04 ; \mathrm{N}=10$ ); depth $4.23-4.83$ (mean $4.48 \pm 0.06 ; \mathrm{N}=10$ ).

Pulo Bakkungaan Kechil. Reef $(5 ; 17.2-28.2 \mathrm{~mm}$.$) and beach$ (19; 31.7-40.6 mm.).

Pulo Nunuyan Laut (2; 38.1-40.1 mm.).

\section{CONGROGADIDAE}

\section{Congrogadus subducens Richardson}

Machaerium subducens Richardson, 1843, Ann. Mag. Nat. Hist., 12: 176Australia.

Congrogadus subducens Günther, 1862, Cat. Fishes Brit. Mus., 4: 388; de Beaufort, 1951, Fishes Indo-Austr. Arch., 9: 384, fig. 55.

Dorsal 74-76; pectoral 10-11; anal 62-64; mid-lateral scales 216-220; total length 44.5-225 mm.; standard length $39.0-219 \mathrm{~mm}$.; head 6.08-7.30; depth 9.82-11.29. 
Two juveniles (39.0-57.9 mm.) have dark-rimmed ocelli on the posterior quarter of the body.

Pulo Nunuyan Laut (5).

\section{BROTULIDAE}

*Dinematichthys iluocoeteoides Bleeker

Dinematichthys iluocoeteoides Bleeker, 1855, Nat. Tijd. Ned. Indië, 8: 319Batu Islands; de Beaufort, 1951, Fishes Indo-Austr. Arch., 9: 438, fig. 79.

Dorsal 82; pectoral 20; ventral 1; anal 62; total length $71 \mathrm{~mm}$.; standard length $62.0 \mathrm{~mm}$.; head 4.11 .

Pulo Bakkungaan Kechil. Reef (1).

\section{PHOLIDICHTHYIDAE}

\section{*Gunellichthys pleurotaenia Bleeker}

Gunellichthys pleurotaenia Bleeker, 1858, Acta Soc. Sci. Indo-Néerl., 3 (Celebes), p. 10-Menado, Celebes; de Beaufort, 1951, Fishes Indo-Austr. Arch., 9: 448 , fig. 86 .

Dorsal 56; pectoral 13; ventral 4; anal 37; total length $38 \mathrm{~mm}$.; standard length $34 \mathrm{~mm}$.; head 6.2; depth 17.0.

Pointed conical teeth in bands in both jaws; innermost row of lower jaw the largest.

According to de Beaufort there are only two rays in each ventral. Otherwise my specimen agrees very well with de Beaufort's description. The color patterns are identical.

Pulo Bakkungaan Kechil. Beach (1).

\section{PLEGTOGNATHI}

\section{TRIACANTHIDAE}

\section{Triacanthus blochi Bleeker}

Triacanthus blochii Bleeker, 1852, Nat. Tijd. Ned. Indië, 3: 81-Singapore.

Dorsal IV-V-i,19-20; pectoral i,11-12; anal i,14-15; total length 50-77 mm.; standard length 40.2-62.6 mm.; head 3.00-3.07; depth 2.42-2.93.

Along sandy beach, four miles north of entrance to Sandakan Harbor (1).

Sandakan Fish Market (3). 


\section{Triacanthus brevirostris Schlegel}

Triacanthus brevirostris Schlegel, 1850, Fauna Japonica, pt. 15, p. 294, pl. 129, fig. 2-Japan.

Dorsal V-i,22-23; pectoral i,11-12; anal i,18-19; total length117-151 mm.; standard length 92.6-120 mm.; head 3.52-3.65; depth 2.70-2.72.

Along sandy beach, four miles north of entrance to Sandakan Harbor (2).

\section{MONACANTHIDAE}

*Cantherines pardalis Rüppell

Monacanthus pardalis Rüppell, 1835, Neue Wirbelth., Fische, p. 57, pl. 15, fig. 3-Tor, Red Sea.

Cantherines pardalis Fowler, 1925, Bull. Bishop Mus., no. 22, p. 20.

Dorsal II-34; pectoral 14; anal 31; total length $160 \mathrm{~mm}$; standard length $135 \mathrm{~mm}$.; head 3.22; depth 1.93 .

Pulo Bakkungaan Kechil. Reef (1).

\section{Monacanthus chinensis Bloch}

Balistes chinensis Bloch, 1786, Ausländ. Fische, 2: 29, pl. 152, fig. 1-China.

Monacanthus chinensis Cuvier, 1817, Règne Anim., 1st ed., 2: 152.

Dorsal II-28-29; pectoral 11-12; anal 27-29; total length 60-64 mm.; standard length 45.0-48.5 mm.; head 2.85-2.93; depth 1.84-2.07.

Pulo Nunuyan Laut (2).

Sandakan Fish Market (3).

\section{Monacanthus tomentosus Linnaeus}

Balistes tomentosus Linnaeus, 1758, Syst. Nat., 10th ed., 1: 328-America (in error).

Monacanthus tomentosus Cuvier, 1817, Règne Anim., 1st ed., 2: 152.

Dorsal II-26-29 (mean 27.9 $\pm 0.4 ; \mathrm{N}=7$ ); pectoral 10-12 (mean $11.0 \pm 0.2 ; \mathrm{N}=7$ ); anal 25-28 (mean $26.6 \pm 0.4 ; \mathrm{N}=7$ ); total length 59-83 mm.; standard length 45.6-64.4 mm.; head 2.85-3.00 (mean $2.91 \pm 0.01 ; \mathrm{N}=7$ ); depth $1.84-1.98$ (mean $1.90 \pm 0.01 ; \mathrm{N}=7$ ).

Pulo Nunuyan Laut (9).

\section{BALISTIDAE}

\section{*Balistapus verrucosus Linnaeus}

Balistes verrucosus Linnaeus, 1758, Syst. Nat., 10th ed., 1 : 328-India.

Balistapus verrucosus Seale, 1906, Occ. Pap. Bishop Mus., 4, no. 1, p. 76. 
Dorsal III-iii,22; pectoral i,12; anal ii,20; mid-lateral scales 40; total length $141 \mathrm{~mm}$; ; standard length $120 \mathrm{~mm}$.; head 2.41; depth 1.96 .

Pulo Bakkungaan Kechil. Reef (1).

\section{Balistes sp.}

Dorsal III-25; pectoral 14; anal 23; total length $31 \mathrm{~mm}$; standard length $24.7 \mathrm{~mm}$.

Coloration pale brown with indistinct dark areas dorsally.

In fin ray counts this specimen is close to rotundatus Proce.

Pulo Bakkungaan Kechil. Beach (1).

\section{TETRAODONTIDAE}

\section{Arothron immaculatus Bloch and Schneider}

Tetraodon immaculatus Bloch and Schneider, 1801, Syst. Ichthy., p. 507no locality.

Arothron immaculatus Fraser-Brunner, 1943, Ann. Mag. Nat. Hist., (11), 10: 15 .

Dorsal 9; pectoral ii,14; anal 9; total length $115 \mathrm{~mm}$.; standard length $85.6 \mathrm{~mm}$.; head 2.63 .

Pulo Bakkungaan Kechil. Reef (1).

\section{*Arothron nigropunctatus Bloch and Schneider}

Tetraodon nigropunctatus Bloch and Schneider, 1801, Syst. Ichthy., p. 507Tranquebar, India.

Arothron nigropunctatus Fowler, 1899, Proc. Acad. Nat. Sci. Phila., 1899: 496.

Dorsal 10-11; pectoral ii,16-17; anal 10-11; total length 79-169 mm.; standard length $65.0-130 \mathrm{~mm}$.; head 2.36-2.49.

Pulo Bakkungaan Kechil. Reef (3).

\section{Arothron reticularis Bloch and Schneider}

Tetraodon reticularis Bloch and Schneider, 1801, Syst. Ichthy., p. 506Malabar.

Arothron reticularis Fowler, 1899, Proc. Acad. Nat. Sci. Phila., 1899: 496.

Dorsal 9; pectoral ii,16; anal 9; total length $127 \mathrm{~mm}$.; standard length $98.2 \mathrm{~mm}$; head 2.30 .

Pulo Nunuyan Laut (1). 


\section{OSTRACIIDAE}

\section{Ostracion cornutus Linnaeus}

Ostracion cornutus Linnaeus, 1758, Syst. Nat., 10th ed., 1: 331-India.

Dorsal ii,7; pectoral 11; anal i, 8; total length $183 \mathrm{~mm}$.; standard length $116.7 \mathrm{~mm}$.; head 3.27; depth 2.64 .

Pulo Nunuyan Laut (1).

\section{DIODONTIDAE}

\section{*Diodon holacanthus Linnaeus}

Diodon holacanthus Linnaeus, 1758, Syst. Nat., 10th ed., 1: 335-India.

Dorsal ii,12-13; pectoral 22-24; anal 12-13; total length 145-228 mm.; standard length 125-185 mm.; head 2.13-2.45.

Pulo Bakkungaan Kechil. Reef (4).

\section{R E F E R E N C E S}

Bleeker, Pieter

1873-76. Atlas ichthyologique des Indes Orientales Néêrlandaises. 7, 126 pp., pls. 279-320. Amsterdam, Muller.

Fowler, H. W., and Bean, B. A.

1928. The fishes of the families Pomacentridae, Labridae, and Callyodontidae, collected by the United States Bureau of Fisheries Steamer "Albatross," chiefly in Philippine Seas and adjacent waters. Bull. U. S. Nat. Mus., no. 100,7 , viii +525 pp., 49 pls.

1930. The fishes of the families Amiidae, Chandidae, Duleidae, and Serranidae, obtained by the United States Bureau of Fisheries Steamer "Albatross" in 1907 to 1910 , chiefly in the Philippine Islands and adjacent seas. Bull. U. S. Nat. Mus., no. 100, 10, ix + 334 pp., 27 figs.

Meek, S. E., and Hrldebrand, S. F.

1923. The marine fishes of Panama. Part I. Field Mus. Nat. Hist., Zool. Ser., 15, xi +330 pp., 24 pls.

Miller, R. R.

1945. Hyporhamphus patris, a new species of hemiramphid fish from Sinaloa, Mexico, with an analysis of the generic characters of Hyporhamphus and Hemiramphus. Proc. U. S. Nat. Mus., 96: 185-193, pl. 11.

Schultz, L. P.

1943. Fishes of the Phoenix and Samoan Islands collected in 1939 during the expedition of the U. S. S. "Bushnell." Bull. U. S. Nat. Mus., no. 180, x + $316 \mathrm{pp} ., 9$ pls., 27 text figs.

1953. Review of the Indo-Pacific anemone fishes, genus Amphiprion, with descriptions of two new species. Proc. U. S. Nat. Mus., 103: 187-201, pls. 9-10. 
Schultz, L. P., and Woods, L. P.

1948. A new name for Synchiropus altivelis Regan, with a key to the genera of the fish family Callionymidae. Jour. Washington Acad. Sci., 38: 419-420.

Weber, Max, and de Beaufort, L. F.

1929. The fishes of the Indo-Australian Archipelago. 5, xiv +458 pp., 98 figs. Leiden, Brill.

1931. The fishes of the Indo-Australian Archipelago. 6, xii +448 pp., 81 figs. Leiden, Brill. 





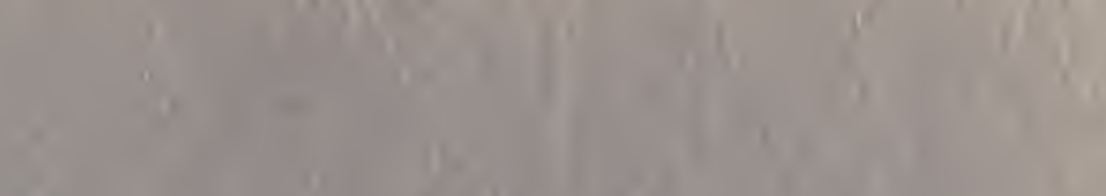

$$
\begin{aligned}
& \text { It } \\
& \text { (1) }
\end{aligned}
$$

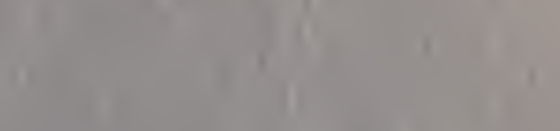

$$
\begin{aligned}
& 1+1 \\
& \text { (1) } \\
& \text { I }
\end{aligned}
$$

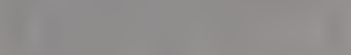

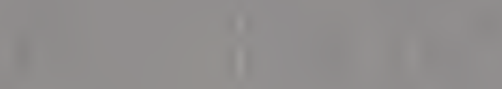

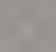

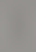

$$
\begin{aligned}
& 10 \\
& x_{2}+1
\end{aligned}
$$

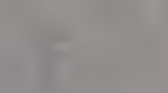

$$
\begin{aligned}
& \text { Y } 10=19
\end{aligned}
$$

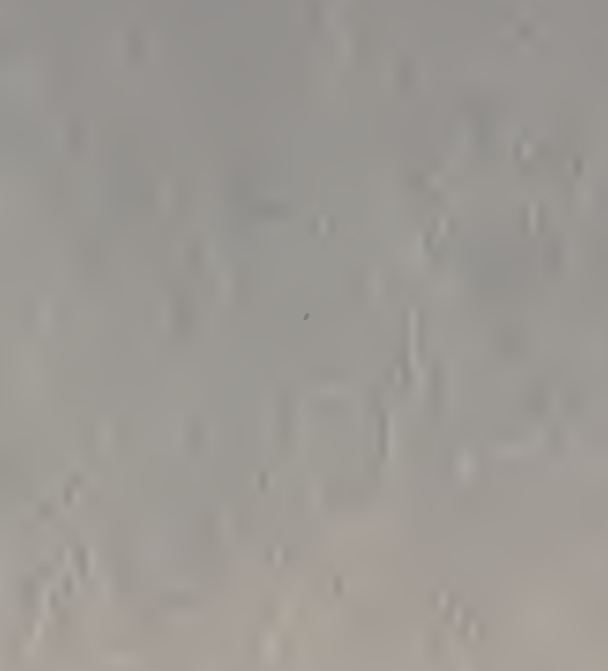

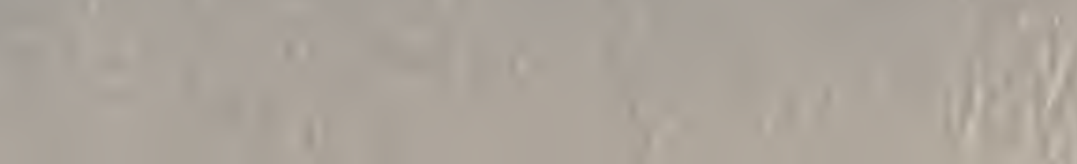

$$
\begin{aligned}
& (11= \\
& \text { (1) } \\
& \sqrt{2} \\
& \text { (n) } \\
& 13
\end{aligned}
$$






$<$ 

UNIVERSITY OF ILLINOIS-URBANA

590.5F1 CO01

FIELDIANA, ZOOLOGYSCHGO

36 1954-58

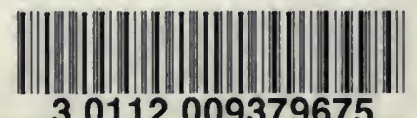

30112009379675 